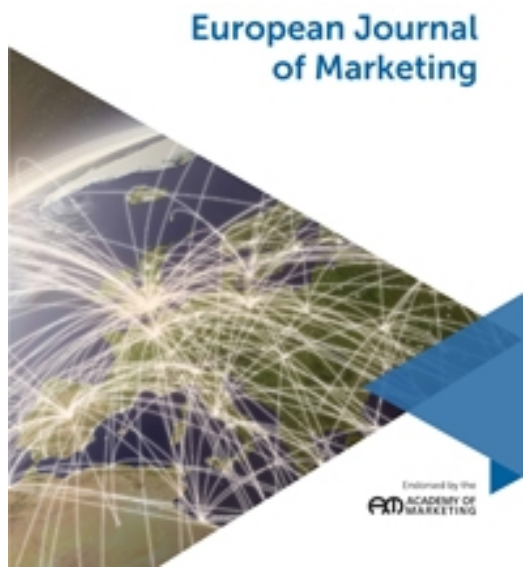

\title{
Modelling multiple forms of consumer animosity through fuzzy-set Qualitative Comparative Analysis
}

\begin{tabular}{|r|l|}
\hline Journal: & European Journal of Marketing \\
\hline Manuscript ID & EJM-04-2020-0272.R3 \\
\hline Manuscript Type: & Original Article \\
\hline Keywords: & $\begin{array}{l}\text { product avoidance, consumer animosity, negative word of mouth, } \\
\text { Product quality, anger, fear }\end{array}$ \\
\hline \multicolumn{2}{|l}{} \\
\hline
\end{tabular}

\section{SCHOLARONE \\ Manuscripts}




\title{
Modelling multiple forms of consumer animosity through fuzzy-set Qualitative Comparative Analysis
}

\begin{abstract}
Purpose - Consumer animosity toward a foreign country can affect negatively international brands. Existing international marketing research offers inconsistent accounts of the factors that explain product quality perceptions, negative word-of-mouth and product avoidance in animosity contexts. Such inconsistency is caused by the fact that different explanations apply to different consumer subgroups. Searching for a single solution thus lead to erroneous predictions for sizable subgroups of consumers.
\end{abstract}

Design/methodology/approach - The study implements a fuzzy-set Qualitative Comparative Analysis to two quantitative surveys examining Chinese consumers' $(\mathrm{N}=$ 476) reactions to Japanese products and American consumers' $(\mathrm{N}=517)$ reactions to Chinese products.

Findings - The analysis yields novel explanations of the outcomes of animosity. Only in some causal configurations reduced quality evaluations explain product avoidance and NWOM, while in the others negative behaviors co-exist with positive quality perceptions. Moreover, negative emotions' role varies across forms of animosity. While anger is often associated with the behavioral outcomes of animosity, fear plays an important role in only a few specific combinations.

Research implications - General models of animosity need to be complemented with accounts that examine the multiple mechanisms underpinning animosity outcomes.

Practical implications - Marketers should identify which animosity model applies to their consumer segment(s) as different mechanisms require different marketing approaches. 
Originality/value - This is the first study recognizing that the same animosity outcomes are explained by multiple mechanisms offering a more nuanced picture of the motivations associated with consumer animosity.

Manuscript type: Research Paper

Keywords: consumer animosity, product avoidance, negative word of mouth, product quality perceptions, anger, fear. 


\section{Introduction}

The international marketing literature defines consumer animosity as "remnants of antipathy related to previous or on-going military, political, or economic events" (Klein et al., 1998, p. 90). International crises of various degrees of seriousness, from war to economic disputes and divergent political or moral views (Abosag and Farah, 2014; Amine, 2008; Ettenson and Klein, 2005), can fuel negative social attitudes toward a foreign country. For example, the Coronavirus (Covid-19) crisis, has led some consumers to criticize or develop a negative association with China as the country from which the virus originally spread (Feng, 2020). Such a negative cognitive and emotional reaction toward a target country can have damaging consequences for important marketing outcomes, such as brand image (e.g., Abosag and Farah, 2014; Leigh and Choi, 2007), brand trust (e.g., Lee and Mazodier, 2015), boycott and product avoidance intentions (e.g., Ettenson and Klein, 2005; Harmeling et al., 2015), negative word of mouth (NWOM; Harmeling et al., 2015) and the ownership of foreign products (e.g., Klein et al., 1998; Gineikiene and Diamantopoulos, 2017). In this study we aim to explore how multiple forms of consumer animosity can coexist in a given international context. In so doing, we show how, within a given relationship (e.g., China-Japan), multiple explanations (rather than just one) account for a certain outcome of animosity (e.g., NWOM).

Despite the valuable insights produced by this body of work, the literature presents some notable inconsistencies. Some studies argue that animosity is independent of product quality perceptions (Fong and Burton, 2008; Funk et al., 2010; Klein, 2002; Maher et al., 2010), while others maintain that hostility negatively affects quality perceptions (Ettenson and Klein, 2005; Leong et al., 2008; Shoham et al., 2006), which in turn explain negative 
behavioral reactions, such as NWOM and product avoidance (Ettenson and Klein, 2005; Huang et al., 2010; Leong et al., 2008). Furthermore, scholars have offered differing accounts to explain the relationship between the negative emotions triggered by animosity (i.e., anger and fear) and important outcomes such as quality perceptions, NWOM and product avoidance. Anger is an agonistic negative emotion which is approach-oriented, while fear is a retreat emotion that is avoidance-oriented (Antonetti, 2016; Antonetti et al., 2019; Harmeling et al., 2015). Harmeling and colleagues (2015) argue that anger causes NWOM and product avoidance as it is an emotion that "energizes the individual to fight against the cause of anger" (pp. 679); while fear influences only product quality perceptions and product avoidance intentions, as "it drives the individual to withdraw" (pp. 679). Other studies, however, argue that anger also explains product quality perceptions (Ettenson and Klein, 2005; Leong et al., 2008).

Such inconsistencies might be caused by the fact that different explanations might apply to different consumer subgroups. Past animosity research has tended to rely on using structural equation modeling (SEM). Consequently, the focus is on finding the causal model that best fits the empirical data (e.g., Ettenson and Klein, 2005; Gineikiene and Diamantopoulos, 2017; Harmeling et al., 2015). However, crises are very complex social phenomena, involving an ever-changing range of social, economic, military and political factors (Brubaker and Laitin, 1998). Despite its merits, the approach to SEM used in past research, is not able to reflect the potential causal complexity of the phenomena analyzed (Woodside, 2013). Specifically, past SEM-based studies on consumer animosity cannot account for 1) cases that contradict the overarching theory tested and 2) the possibility that multiple causal combinations yield the same outcome (i.e., equifinality). Importantly, 
while there are approaches to SEM that allow accounting for the effect of heterogeneity (Jedidi et al., 1997) these have not been explicitly considered and past literature has proceeded to the estimation of a single model that applies to the whole sample.

Adopting a complexity theory perspective, we explore the possibility that the single solutions proposed by earlier research might hide many different forms of animosity (Zyphur, 2009). The focus switches from searching for the model that best fits the data and captures the highest share of variance in the outcomes of interest, to theorizing the different, co-existing models of animosity (Ragin, 2008; Woodside, 2013; Zyphur, 2009). Such a change in mindset implies that, rather than relying on a single model of animosity, international brand managers should consider which model of animosity best applies to their unique circumstances. To achieve this goal, we implement a fuzzy-set Qualitative Comparative Analysis (fsQCA; Ragin, 2008) to theorize and explore the simultaneous operation of a constellation of different causal conditions that might explain how international crises influence consumers' behavior toward brands. FsQCA is attracting increasing attention from management and marketing scholars (Fiss, 2011; Schneider and Eggert, 2014) for its ability to explore equifinality, which is the idea "that a system can reach the same final state from different initial conditions and by a variety of different paths" (Katz and Kahn, 1978, pp. 30). Specifically, fsQCA enables the identification of different models of animosity that explain important consumer outcomes (Fiss, 2011).

This novel approach develops three contributions. First, it demonstrates that animosity outcomes (i.e., product quality perceptions, NWOM and product avoidance) can be explained by multiple causal recipes. Past research needs to be complemented by an understanding of the causal complexity underpinning animosity. Several configurations of 
causal conditions, rather than just one, explain how international crises affect consumer behavior. Furthermore, through the examination of China-Japan and USA-China animosity, the study shows that causal configurations vary across crises. A second contribution lies in clarifying the inconsistency in earlier research on whether animosity outcomes are linked to quality perceptions (Fong and Burton, 2008; Ettenson and Klein, 2005). The study shows that two different forms of animosity exist, both supported by the data. While for some consumers, reduced quality evaluations explain product avoidance and NWOM, others act negatively toward products from the target country even though they consider them as being of high quality. A third contribution relates to explaining the role of negative emotions in animosity. Past research has argued that anger and fear play an important role in explaining the outcomes of animosity (Harmeling et al., 2015; Jung et al., 2002). This study shows that the role of these emotions varies across configurations. While anger is often an important cause of the outcomes of animosity in most consumers and in most cases, fear appears to be critical in only a few causal combinations. Importantly, our causal configurations show that negative consumer reactions can occur in the absence of fear. This is however less often the case with anger, suggesting a more central role of this emotion. In general, our findings show that different emotions play a critical role in different forms of animosity.

\section{Conceptual development}

Consumer animosity: key findings and assumptions in the literature

Animosity is conceptualized as originating in a crisis that damages international relations between two countries (Klein et al., 1998). Such worsening of relations leads consumers to develop a hostility toward a foreign country and such negative perception is 
likely to linger and affect how consumers perceive brands from the target country over time (Harmeling et al., 2015; Klein et al., 1998). When the crisis is extremely serious and intense, as in the case of Japan's invasion of China during World War II, animosity can remain as a lasting negative perception able to influence negatively the perception of Japanese products decades after the incident (Klein et al., 1998). In other cases, animosity can be situational rather than stable (Guido et al., 2010), as in the political controversy between France and the USA at the time of the 2003 invasion of Iraq. Animosity can lead to a situational dislike and antipathy that have only temporary effects on consumers that dissipate over time (Amine, 2008, Leong et al., 2008).

Research on consumer animosity, its determinants and its consequences, has progressed enormously over the last two decades. One constant in the literature, however, has been the use of SEM or other similar techniques to estimate statistically the causal relationships between different constructs (e.g. Harmeling et al., 2015; Klein et al., 1998; Lee et al., 2017; Reifler and Diamantopoulos, 2007). Existing studies, therefore, examine the extent to which one overarching model fits the data, but do not discuss the potential heterogeneity that, within a given sample, might characterize reactions to international crises. However, substantial evidence suggests that simply establishing the existence of a relationship between two variables in a dataset represents a significant loss of information (Woodside, 2013). Within the same dataset, the two variables might be positively related, negatively related or not associated at all (Schneider and Eggert, 2014; Woodside, 2013). Complexity theory and fsQCA allow us to explore the possibility of multiple realities, whereby the outcomes of animosity are explained by different causal configurations, rather than just one (Urry, 2005). The goal of this study is to complement existing research with 
a complexity theory perspective that can identify a typology of the main explanatory models accounting for the outcomes of animosity.

A further assumption of earlier research is that a model of animosity developed for a specific international relation (e.g., the animosity felt by Chinese consumers toward Japan) can also explain animosity in another context (e.g., the animosity felt by American consumers toward China). As discussed above, however, international crises tend to be very diverse (Brubaker and Laitin, 1998) and consequently it seems reasonable to expect much more heterogeneity across crises. Deploying fsQCA across two different contexts also allows to test this assumption and consider explicitly the possibility that there might be significant diversity in the causal configurations identified across crises.

In what is the only empirical typology of animosity published to date, Jung et al. (2002) differentiate between four forms of hostility, depending on whether animosity is situational or stable and dictated by mostly personal or national motivations. Guido et al. (2010) propose a similar classification when reviewing the existing literature. These analyses however do not study the antecedents commonly examined in the international marketing literature, which include cognitive evaluations of the target country (i.e., animosity beliefs) and negative emotions elicited by the target country (Abosag and Farah, 2014; Ettenson and Klein, 2005; Klein et al., 1998). Scholars often conceive emotions as mediating the effect of cognition on behavior (Harmeling et al., 2015).

This study starts from one published model of animosity, and then tests whether a single or multiple causal interpretations emerge once the relevant variables are examined through fsQCA. This approach allows to verify whether it is reasonable to assume the absence of equifinality in the data (see Schlittgen et al., 2016 for a similar application), something that 
has never been ruled out in previous research. To achieve this goal, we start from the conceptual model of animosity proposed by Harmeling et al. (2015) a suitable starting point because 1) it was published in a leading outlet for international business research, 2) it appears consistent with earlier studies in its explanatory logic (Ettenson and Klein, 2005; Klein et al., 1998), and 3) it offers a comprehensive model for how cognitions and emotions explain the outcomes of animosity. Harmeling et al. (2015) suggest that military beliefs (i.e., the perception of the target country as an enemy) influence feelings of fear and anger. Anger, in turn, causes NWOM and product avoidance, while fear influences product quality perceptions and product avoidance intentions. Finally, product quality perceptions explain NWOM and product avoidance. This study focuses on the variables adopted by Harmeling et al. (2015), but considers explicitly whether multiple causal explanations, in addition to those offered by their model, might coexist.

\section{A complexity perspective on consumer animosity}

Linear modeling techniques test the extent to which a single model explains the outcomes of interest (Woodside, 2013). On the contrary, a configurational, set-theoretic approach based on fsQCA (Ragin, 2008) explicitly tests the possibility that multiple causal combinations can explain the dependent variables (Woodside, 2013). FsQCA takes a person-centered (or case-based) perspective and identifies the causal configurations that explain outcomes at the individual level. This approach views cases as a combination of attributes: causal conditions and outcome conditions, which can be seen as independent and dependent variables, respectively (Ragin, 2008). Based on Boolean algebra, fsQCA assumes that relationships can be best understood in terms of set membership and set relations. FsQCA thus examines the level of conjunction (or disjunction) between 
variables, which indicates the extent to which a certain case displays, for example, both high levels of animosity and high product quality perceptions. FsQCA determines which cases show desired values for an outcome by assessing the degree to which causal conditions or configurations of these conditions are present, thus linking membership in the outcome with membership of one or more causal condition(s) (Ragin, 2008; Woodside, 2013).

The study focuses on the relationships between six different variables (or sets). These include a cognitive measure of war beliefs and two different emotions: anger and fear. The outcomes of animosity considered comprise perceived quality, NWOM, and avoidance. All scales are based on Harmeling et al. (2015). Our fsQCA study, assesses the extent to which every case belongs (or not) to different sets (i.e., variables) and then considers the overlap between the different conditions. For example, previous research suggests that cases belonging to the set "anger" should also belong to the set "NWOM" (i.e., if someone displays a high degree of "anger", he or she should also display the property "NWOM"; Harmeling et al., 2015).

\section{Testing the equifinality proposition}

A complexity theory perspective considers the possibility that, rather than being explained by a single configuration of variables, a phenomenon of interest is best explained by multiple configurations (Urry, 2005). The recognition that not one but multiple configurations of causal conditions explain product quality perceptions, NWOM and product avoidance raises two implications. First, current and future contributions based on SEM models need to consider the existence of significant heterogeneity and causal complexity in the data. This means that the predictions developed through modeling might 
not apply to a sizeable group of consumers (Woodside, 2013). Therefore, scholars should explicitly test for heterogeneity in the data (Jedidi et al., 1997). Second, if multiple causal explanations exist, then a key task of future research is to identify what triggers the shift from one causal explanation to another. To explore the existence of different forms of animosity, the study advances the following research propositions for the three outcomes considered:

P1a: Multiple configurations of animosity beliefs, anger, and fear best explain product quality perceptions, rather than a single configuration.

P1b: Multiple configurations of animosity beliefs, anger, fear, and product quality perceptions best explain product avoidance, rather than a single configuration.

P1c: Multiple configurations of animosity beliefs, anger, fear, and product quality perceptions best explain NWOM rather than a single configuration.

The necessary and sufficient features of animosity

Complexity theory (Urry, 2005) and the equifinality principle (Ragin, 2008) allow for the possibility that one antecedent might be central in one causal combination, but absent in another. This means that, for example, while anger appears very important in most animosity studies (Harmeling et al., 2015; Klein et al., 1998; Klein, 2002), some causal configurations may not include it.

An antecedent condition present in every causal configuration is necessary to explain the outcome (Ragin, 2008). In other words, a necessary causal condition always appears in conjunction with the outcome of interest. In contrast, a condition that is only present in one or a few combinations can be considered sufficient but not necessary (Ragin, 2008). The analysis of necessity and sufficiency can help highlight fundamental conditions for 
animosity, as research is unclear on this point. Most accounts suggest that animosity stems from negative cognitions and negative emotions about the company (e.g., Harmeling et al., 2015; Klein et al., 1998; Klein, 2002). However, the literature is unclear as to which emotions should be considered especially important. Most studies designate anger (e.g., Abosag and Farah, 2014; Harmeling et al., 2015; Klein et al., 1998; Klein, 2002), while a few designate fear (Harmeling et al., 2015; Jung et al., 2002). However, some empirical investigations of animosity do not consider the role of emotions at all (e.g., De Nisco et al., 2016; Heinberg, 2017). Despite such variations in existing accounts, most of the available evidence suggests that animosity beliefs and anger are necessary to explain the outcomes of animosity (Harmeling et al., 2015; Klein et al., 1998; Klein, 2002). To examine this possibility formally the study advances the following research propositions:

P2a: Animosity beliefs and anger are necessary to explain product quality perceptions ${ }^{1}$.

P2b: Animosity beliefs and anger are necessary to explain NWOM.

P2c: Animosity beliefs and anger are necessary to explain product avoidance.

\section{Revisiting inconsistencies in current accounts}

The reliance on linear modeling in past research also means that contradictory findings across studies are difficult to reconcile conceptually (Woodside, 2013). If two variables correlate in one study, they should correlate in another, unless some new construct has been added to the model. Complexity theory makes it possible to justify inconsistencies not by adding more variables to the analysis but simply by allowing for multiple causal recipes to explain the outcome of interest (Ragin, 2008; Woodside, 2013).

\footnotetext{
${ }^{1}$ The expectation is that the absence of animosity beliefs and anger should lead to the presence of product quality perceptions. To simplify our presentation we do not consider conditions that predict the absence of product quality perceptions, since such an analysis would yield no additional insights in this specific study.
} 
One area of current research that presents inconsistent findings concerns the role of product quality perceptions in existing animosity models. Seminal animosity studies indicate that the negative effects of cognitive and emotional animosity on a foreign brand should be entirely independent of product quality perceptions (Klein et al., 1998). Several investigations support this view (Fong and Burton, 2008; Funk et al., 2010; Klein, 2002; Maher et al., 2010), while others do not. Scholars have found that product quality perceptions is negatively influenced by animosity beliefs and negative emotions toward a target country (Ettenson and Klein, 2005; Leong et al., 2008). This effect means that negative behavioral reactions such as product avoidance and NWOM are more likely, since the perceived quality of foreign products is lower (Gineikiene and Diamantopoulos, 2017; Harmeling et al., 2015). FsQCA allows for the possibility that the two views are complementary rather than alternative. Specifically, negative behavioral reactions to foreign brands (i.e., NWOM and product avoidance) are expected to co-exist in some causal recipes with high product quality perceptions, while being linked in others to low product quality perceptions. Consequently, this study proposes the following research propositions:

P3a: In configurations that explain NWOM, both the presence and absence of product quality perceptions contribute to the outcome of interest, depending on how this condition forms a causal recipe with other antecedents.

P3b: In configurations that explain product avoidance, both the presence and absence of product quality perceptions contribute to the outcome of interest, depending on how this condition forms a causal recipe with other antecedents. 
The literature has also produced contradictory findings in relation to the role of fear in animosity. Harmeling et al. (2015) demonstrate that fear plays a significant role in explaining product avoidance. Their findings suggest that emotions expressing anxiety and concern are an important antecedent of negative behaviors toward international brands (Jung et al., 2002). These findings however are contradicted by recent evidence questioning the importance of fear as an explanatory mechanism for behavioral outcomes, and suggesting that more extreme emotions (such as disgust and contempt) better explain NWOM and product avoidance (Antonetti et al., 2019). The exploration of equifinal causal recipes investigates the possibility that fear might play a role in only certain causal configurations. This study suggests the following propositions about the role of fear as an antecedent across multiple animosity models.

P4a: In configurations that explain NWOM, both the presence and absence of fear contribute to the outcome of interest, depending on how this condition forms a causal recipe with other antecedents.

P4b: In configurations that explain product avoidance, both the presence and absence of fear contribute to the outcome of interest, depending on how this condition forms a causal recipe with other antecedents.

\section{Research approach}

Data collection and sample characteristics

The study examines two different animosity contexts. Data was collected from Chinese participants evaluating Japan, and from American participants evaluating China. The former animosity context has substantial historical roots, with animosity mostly being linked with the atrocities committed by the Japanese army in certain areas of China during 
World War II (Christensen, 1999). The animosity between the USA and China has different dimensions. Political and military tensions date back to the Cold War and the role played by China in the Korean War and its aftermath (Christensen, 1999). In the last decade, the relations between countries have been also complicated by commercial disputes (Liu, 2018). Research suggests that both contexts are appropriate to examine consumer animosity as there is evidence of significant animosity toward Japan in China and toward China in the USA (Harmeling et al., 2015). During the time of data collection (approximately one week for each study during May 2016), there were no specific incidents reported in the news that might have reignited the disputes and thus affected our results.

Two online surveys collected nationally representative data in China (evaluating Japan) and the USA (evaluating China) via a commercial panel firm (Survey Sampling International). An instrumental manipulation check appeared at the beginning of the survey to maximize participants' engagement and ensure their attention (see Oppenheimer, Meyvis and Davidenko, 2009 for details). An attention check question appeared toward the end of the survey (Meade and Craig, 2012). Participants who failed this attention check were excluded from the dataset.

A total of 476 Chinese and 517 American respondents completed the two surveys. Both surveys were balanced between genders (males in China: 55\%; males in the USA: 48.5\%). In China, the largest proportion of participants was between 25 and 34 years old $(27.5 \%)$, followed by 35 to 44 years old (22.5\%), 45 to 54 years old (20.4\%), 18 to 24 years old $(18.9 \%)$ and 55 or older $(10.7 \%)$. In the USA, the largest proportion of participants was between 45 to 54 years old (23.4\%), followed by 55 or older $(21.4 \%), 35$ to 44 years old (20.7\%), 25 to 34 years old (20.7\%), and 18 to 24 years old (13.7\%). 


\section{Measurement model assessment and validation}

The USA survey was based on work by Harmeling et al. (2015). It was translated into Chinese and back-translated into English by two professional market researchers, to ensure consistency between the two samples. The same items appeared in both surveys. Animosity beliefs focused on military tensions. Scales also captured anger, fear, product quality perceptions, NWOM and product avoidance. All scales were measured on a 7-point scale.

In both countries/samples, all constructs' Cronbach's alphas, composite reliability and average variance extracted scores exceed the commonly used thresholds of .7 (Nunnally, 1978), .6 and .5, respectively (Bagozzi and Yi, 1988), as per Table 1. An analysis of discriminant validity, in line with Fornell and Larcker (1981), reveals that the average variance extracted for each construct, in both countries/samples, is greater than the squared correlations, as per Table 2 in the manuscript. Table 2 also shows the means and standard deviations of each construct in the two surveys. Lastly, an assessment of variance inflation factors (VIF) shows no multi-collinearity concerns between the variables in both countries/samples (O’Brien, 2007).

To assess measurement model fit in the two samples, a multi-group analysis was conducted using IBM SPSS AMOS (version 22). The measurement models in both countries/samples have an overall acceptable model fit (China: $\chi^{2}=540.289$, df $=215$, $\chi^{2} / \mathrm{df}=2.51, \mathrm{CFI}=.97, \mathrm{TLI}=.97, \mathrm{RMSEA}=.05, \mathrm{SRMR}=.05 ; \mathrm{USA}: \chi^{2}=702.01, \mathrm{df}=$ $\left.215, \chi^{2} / \mathrm{df}=3.26, \mathrm{CFI}=.96, \mathrm{TLI}=.95, \mathrm{RMSEA}=.07, \mathrm{SRMR}=.04\right)$. However, metric invariance across groups is not supported $\left(\Delta \chi^{2}=42.74, \Delta \mathrm{df}=18, p<.01\right)$. This is due to one item for fear (i.e., worried) and one item for product quality perceptions (i.e., Japanese (Chinese) products are likely to be technologically very advanced) performing very 
differently across samples (see Table 1). Once constraints for these two items have been relaxed (Byrne et al., 1989), partial metric invariance is achieved $\left(\Delta \chi^{2}=21.45, \Delta \mathrm{df}=16\right.$, $p=.16$ ), which, given the objectives of this study, appears satisfactory (Byrne et al., 1989; Steenkamp and Baumgartner, 1998).

\section{INSERT TABLES 1 AND 2 HERE}

To minimize the potential effects of common method bias (CMB) all scales were randomized and participants were assured of the confidentiality of the questionnaire (Podsakoff et al., 2003). To check the potential impact of CMB statistically, a marker variable appeared in the questionnaire [i.e., "I prefer warm colors (i.e., containing yellow and red) over cold colors (i.e., containing blue)"'] (Bagozzi, 2011) and partial correlations controlled for this marker variable were examined. None of the constructs in either survey correlates with the marker variable, and the correlations between the constructs of interest do not change in either sample once the marker is introduced as a control.

In addition, we compared our measurement model to two alternatives (Widaman, 1985): 1) a method model where all indicators are loaded on a single-factor model and 2) to a traitmethod model where a single factor containing the method effect is added to the multifactor measurement model. In both samples, we find that the multifactor model fit the data much better than the single-factor model with all indicators loaded on a single factor (China: $\chi^{2}$ $=6535.21, \mathrm{df}=230, \chi^{2} / \mathrm{df}=28.41, \Delta \chi^{2}=5994.92, \Delta \mathrm{df}=15, p<.001 ; \mathrm{USA}: \chi^{2}=7365.33$, $\left.\mathrm{df}=230, \chi^{2} / \mathrm{df}=32.02, \Delta \chi^{2}=6663.32, \Delta \mathrm{df}=15, p<.001\right)$. A trait-method model however offers an improvement in terms of fit in both samples (China: $\chi^{2}=388.3$, df $=197, \chi^{2} / \mathrm{df}=$ 1.97, $\Delta \chi^{2}=151.99, \Delta \mathrm{df}=18, p<.001 ; \mathrm{USA}: \chi^{2}=499.32, \mathrm{df}=197, \chi^{2} / \mathrm{df}=2.53, \Delta \chi^{2}=$ 202.70, $\Delta \mathrm{df}=18, p<.001)$. Moreover, in Table 1 we show the standardized loadings when 
controlling for CMB. The influence of $\mathrm{CMB}$ on the standardized loadings is negligible. Overall, we conclude that, while the method factor contributes to explaining a component of variance in the measurement model, $\mathrm{CMB}$ is not a significant threat in either country/sample.

Data analysis

FsQCA expresses the links between causal and outcome conditions in terms of necessity (i.e., a causal condition is necessary but not sufficient for the outcome to occur) or sufficiency (i.e., a causal condition or combination is sufficient but not necessary for an outcome) (Ragin, 2008). To examine which combinations of causal conditions are necessary and/or sufficient for the outcomes, the researchers calibrated the fuzzy sets, constructed the truth tables, and subsequently analyzed them (Fiss, 2011; Ragin, 2008).

To transform the construct measures into fuzzy-set membership scores, they were calibrated using three qualitative anchors (Ragin, 2000): the threshold for full membership in the set (cases that receive a score of 1), the threshold for full non-membership in the set (cases that receive a score of 0 ), and the crossover point reflecting ambiguity in membership (cases that receive a score of .5). Given that all constructs were measured on a 7-point scale, and following established practice in fsQCA research (e.g., Leischnig and Woodside, 2017), the thresholds were 7 (for full membership), 1 (for full nonmembership), and 4 (as crossover point), respectively. This calibration method can produce fuzzy-set membership scores of exactly .5, so to address this ambiguity issue, a constant of .001 was added to the fuzzy-set membership scores for all conditions below full membership (Fiss, 2011). The fs/QCA software program (Ragin and Davey, 2016) was used for calibration and the same procedure was used for both animosity contexts examined 
(i.e., China/Japan, USA/China).

The same software program was used to construct and analyze the truth tables (all truth tables are reported in the Web Appendix). Since fs/QCA only considers one outcome condition at a time, this study created three truth tables (one for each outcome: product quality perceptions, NWOM, product avoidance) for each animosity context (i.e., 6 truth tables in total). Frequency (i.e., empirical representation) and consistency (i.e., "how closely a perfect subset relation is approximated," Ragin, 2008, pp. 44) were used to refine the truth tables before the analysis. Frequency is assessed because configurations with a small number of empirical instances are not considered sufficiently representative (Leischnig and Woodside, 2017; Ragin and Fiss, 2008). According to Greckhamer et al. (2013) the analysis should be based on at least $80 \%$ of all of the empirical cases. Consistency is assessed because perfect subset relations are very rare and thus, according to Ragin (2006), the analysis should be based on a consistency level of at least $.75^{2}$. We also considered the issue that in some cases fsQCA can offer a configuration that explains both a certain outcome and its negation. This would mean that a configuration could simultaneously explain the presence and the absence of the outcome NWOM. To examine this logical contradiction, the literature has proposed the measure of Proportional Reduction in Inconsistency (PRI). This stricter measure of consistency is used to exclude combinations presenting a PRI lower than .50 (Greckhamer, 2016).

Taking into account these three considerations (empirical representation, consistency and PRI), we proceeded with the data analysis. Tables 3 and 4 report the results of the analysis and can be used to test the research propositions. Consistency scores are very high

\footnotetext{
${ }^{2}$ While fsQCA is incommensurable with SEM, it is possible to consider the consistency indicator as a general measure of fit as it suggests to what extent the data reflect a possible set of postulated relations.
} 
for all solutions calculated. In the American sample, however, we have discarded the analysis of the truth table for product quality perceptions since the PRI was below .50 for all combinations. In the Chinese sample, we have exceptionally included one solution with a PRI of .48 because this allows obtaining one further combination which we consider informative (see Table 3 for details). All other solutions are obtained implementing the following three choices. First, we systematically aimed to include the largest empirical representation possible in the analysis. Second, we excluded rows with PRI below $.50^{3}$. Third, we set the consistency cutoff point excluding values below .75 and following the recommendations by Schneider and Wagemann (2010) that suggest ordering consistency values from the largest to the smaller to identify dips in the distribution to determine the consistency level threshold. This procedure also allows dealing with the risk of potential model ambiguity (Baumgartner and Thiem, 2017) as we found that, following these procedures, only one clear solution emerged from the data. The Web Appendix presents all the information concerning consistency and PRI for all truth tables and indicates the rows selected for analysis in each case.

The analysis of the truth tables focused on the parsimonious and intermediate solutions, which consider logical remainders (i.e., configurations that lack sufficient empirical manifestation). Fiss (2011, pp. 403) notes that “...core conditions are those that are part of both parsimonious and intermediate solutions, and peripheral conditions are those that are eliminated in the parsimonious solution and thus only appear in the intermediate solution." Core conditions are essential for the outcome to occur, while peripheral

\footnotetext{
${ }^{3}$ Out of all the truth table rows (i.e., combinations) considered across our analyses 22 respect the even stricter PRI criteria of being above .75 (Greckhamer, 2016). Five are between .60 and .75 and five are between .50 and .60 .
} 
conditions reinforce the outcome. Raw and unique coverage scores (Fiss, 2011; Ragin, 2008) indicate the extent to which a solution explains the outcome (Leischnig and Woodside, 2017) and are used to evaluate the representativeness of different configurations. Raw coverage indicates the percentage of cases (i.e., participants) that can be described by a given causal configuration (Schneider and Wagemann, 2010). Unique coverage relates instead to the share of cases that are uniquely accounted for by the specific solution examined (Schneider and Wagemann, 2010). Using the notation developed by Ragin and Fiss (2008) Tables 3 and 4 illustrate the presence $(\bullet)$ or negation/absence $(\otimes)$ of core (i.e., large circles) and peripheral (i.e., small circles) conditions for each outcome examined as well as the relative coverage to assess the representativeness of each solution.

\section{INSERT TABLES 3 AND 4 HERE}

\section{Findings}

The key findings with regard to the Chinese sample are as follows. There is clear evidence of equifinality for at least two out of three outcomes (e.g., product quality perceptions and product avoidance). Consequently, P1a and P1c are supported by the data. Evidence on P1b is less clear. Although the first solution rests on a marginally low PRI (.48), we interpret the data as suggesting equifinality given the high consistency and coverage scores obtained. The different solutions follow two general interpretations. One interpretation suggests that international crises create uniformly negative reactions toward the target country (product quality perceptions solution 3; NWOM solution 2; product avoidance solution 2). A second interpretation suggests that negative and positive reactions coexist (product quality perceptions solutions 1 and 2; product avoidance solution 3). Importantly, solution 3 for product quality perceptions and 4 for product avoidance show 
novel causal configurations that apply to a sizable subgroup of consumers but have been overlooked in previous research. The raw coverage shows that solution 3 for product quality perceptions applies to $37 \%$ of the sample (with a unique coverage of $10 \%$ ). This solution indicates that a sizable group of consumers can believe that products from Japan are high quality, while at the same time holding negative emotions toward the country (anger and fear) and believing that Japan is an enemy of China. Solution 3 for product avoidance applies to $65 \%$ of the sample (with a unique coverage of $9 \%$ ) and suggests that Chinese consumers can avoid products from Japan while being fearful of the target country, having high military beliefs, but also seeing Japanese products as high quality. The idea that both the presence of fear and the presence of high quality perceptions can predict negative outcomes complements previous SEM-based findings that suggested a negative correlation between these two variables (Harmeling et al., 2015).

The presence of animosity beliefs and anger is necessary to explain NWOM but not necessary to explain product avoidance or quality perceptions. This result supports $\mathrm{P} 2 \mathrm{~b}$, but not $\mathrm{P} 2 \mathrm{a}$ and $\mathrm{P} 2 \mathrm{c}$. Finally, the causal configurations support $\mathrm{P} 3 \mathrm{~b}$ and $\mathrm{P} 4 \mathrm{~b}$ while $\mathrm{P} 3 \mathrm{a}$ and P4a are not supported. A sizable group of participants report acting negatively despite believing in the quality of the products from the target country. However, other combinations show that negative evaluations of products from the target country partly explain NWOM and product avoidance. Meanwhile, the current findings suggest that the presence of fear is a central condition in only a few causal recipes. In several solutions negative outcomes are explained by the absence of fear - suggesting that the active role of this emotion is limited to a subset of consumers. Considering the raw coverage scores, we 
find that fear is not important for $40-60 \%$ of the sample (depending on the solution considered).

The American sample, despite being limited to only two outcomes, presents an even larger range of causal configurations accounting for the data set. P1b, P1c, P3a, P3b, P4a and $\mathrm{P} 4 \mathrm{~b}$ are supported by the data. $\mathrm{P} 2 \mathrm{a}, \mathrm{P} 2 \mathrm{~b}$ and $\mathrm{P} 2 \mathrm{c}$ however are not supported by the data since neither animosity beliefs nor anger appear to be necessary conditions even though they (and especially the former) appear in many causal configurations. In this respect, solution 5 for product avoidance reveals an interesting causal configuration. An absence of animosity beliefs and anger, alongside the presence of fear and high quality perceptions, explains avoidance for a subgroup of consumers (33\% raw coverage with $1 \%$ unique coverage). This unique explanation, which had been overlooked in past research, has a nonnegligible empirical relevance and is based on perceptions of the target country as a threat only because of its achievements, but not because of any perceived enmity between the two countries. Another interesting combination is solution 2 for NWOM characterized by the presence of animosity beliefs and fear but the absence of anger and product quality perceptions ( $41 \%$ raw coverage with $6 \%$ unique coverage). This combination is interesting because past research assumes that animosity beliefs and anger are always positively associated while this solution shows that some forms of NWOM do not rely on the activation of anger.

For comparison purposes we also reexamined the data using SEM, consistent with previous research. The structural models for both samples yield an acceptable model fit. The findings of the SEM analysis are entirely consistent with Harmeling et al. (2015) and show that animosity beliefs influence negative emotions, which, in turn, affect the three 
outcomes considered. This comparison stresses how linear modeling applied to consumer animosity risks underplaying the phenomenon's causal complexity. Specifically, considering the Chinese sample, the SEM analysis would contradict the findings reported in solution 3 for product quality perceptions, in solution 2 for NWOM and in solutions 1, 3 and 4 for product avoidance. Similarly, the findings of the SEM analysis for the US sample fail to account for solution 2 for NWOM and the solutions 1, 2, 4 and 5 for product avoidance. Thus, fsQCA offers a complementary approach to SEM that is beneficial to researchers.

\section{Discussion}

\section{Theoretical implications}

This study demonstrates that animosity is characterized by equifinality, a feature overlooked in past research, which can explain previous inconsistent findings in relation to outcomes and the role of emotions in consumer animosity (Jedidi et al., 1997). The shift from a single solution to a complexity theory perspective, a paradigm that accepts the coexistence of multiple solutions, contributes to the consumer animosity literature by demonstrating that different forms of animosity exist with different features. It is not acceptable to ignore the multiplicity of causal configurations that apply better to specific consumer subgroups. Some causal configurations directly contradict the results that a SEM analysis would generate. Specifically, in the China sample, solution 3 for product quality perceptions, solution 2 for NWOM and solutions 1,3 and 4 for product avoidance contradict the results of SEM-based analysis (e.g., Harmeling et al., 2015). Yet, these solutions are representative of large segments of consumers, $37 \%, 50 \%, 69 \%, 46 \%$ and $45 \%$ respectively. Similarly, in the USA sample, solution 2 for NWOM and the solutions 
$1,2,4$ and 5 for product avoidance, which have a raw coverage of $42 \%, 56 \%, 60 \%, 42 \%$ and 34\%, appear to contradict existing research (Harmeling et al., 2015). Consequently, ignoring heterogeneity is not tenable as it undermines the causal complexity of animosity and can lead to incorrect predictions for sizable subgroups of consumers.

The study also finds evidence of significant differences between contexts, so that the causal configurations identified in the Chinese context differ from those identified in the US context. This finding illustrates that another implicit assumption of current research, the idea that the mechanisms explaining the outcomes of consumer animosity are similar across crises, needs a more explicit consideration. Recognizing the role of equifinality substantially reorients current debates. Three key consequences are important for both scholars and managers. First, it will be necessary to understand which animosity model best applies to a given context. Second, it will be necessary to theorize the conditions that cause the shift from one form of animosity to the other. Third, it will be interesting to theorize the characteristics of international relations that are likely to lead to a certain form or model of animosity.

Beyond this general contribution to the way in which consumer animosity is conceptualized in the marketing literature, the study also contributes to existing debates by demonstrating that in some configurations animosity is independent of product quality perceptions, while in others the hostility also affects quality perceptions. Past research results were inconsistent, with some studies supporting the former view (Fong and Burton, 2008; Funk et al., 2010; Klein, 2002; Maher et al., 2010) and others supporting the latter (Ettenson and Klein, 2005; Leong et al., 2008). To explain this inconsistency, scholars have tended to include new variables in their linear models (e.g., Antonetti et al., 2019; 
Harmeling et al., 2015) while they have overlooked the possibility that different explanations might apply to different subgroups. On the contrary, extant research has assumed that only one of the two accounts can ultimately be correct: animosity is either independent of or negatively associated with product quality perceptions. Complexity theory argues that this is a false dichotomy. Both models apply to animosity, and their relative suitability depends on the consumer subgroup examined.

The importance of equifinality in animosity also relates to theorizing the role of emotions in animosity. Some scholars have in the past argued that product quality perceptions is negatively influenced by negative emotions toward a target country (Ettenson and Klein, 2005; Leong et al., 2008); while others have found that discrete emotions have different effects on outcomes (Antonetti et al., 2019; Harmeling et al., 2015). From this perspective, the study makes two contributions to the literature. First, it shows that anger, while present in many causal configurations, is not a necessary explanatory mechanism. Particularly in the American sample, some causal configurations do not require anger to explain NWOM or avoidance. Second, we demonstrate that fear is an important explanatory variable in only a few causal configurations. Some past evidence suggests that this emotion reduces product quality perceptions and increases product avoidance (Harmeling et al., 2015). Our evidence suggests that 1) fear can be present together with product quality perceptions (e.g., solution 4 for China and 5 for the USA in the explanation of product avoidance and solution 3 in the USA for the explanation of NWOM) and 2) product avoidance can be present in the absence of fear (solutions 1 and 3 for China and solutions 1 and 4 for the USA). This evidence suggests something new about the role of fear. It seems that fear is important to some consumers but not to others (Jung 
et al., 2002). This distinguishes it from anger, which appears to explain negative consumer outcomes in many more combinations.

Finally the analysis shows that, while animosity beliefs and anger explain animosity in most causal combinations, they cannot be considered necessary features of animosity outcomes; which comes in contrast to the majority of prior animosity research (Harmeling et al., 2015). This means that in some causal configurations, NWOM and product avoidance can be explained by other variables. This is especially the case in the American sample for product avoidance, where the fifth configuration is explained by fear and product quality perception and by the absence of animosity beliefs and anger. This combination identifies a specific type of negative reaction to Chinese products: consumers who are fearful of China are likely to engage in product avoidance even though they do not see China as an enemy and do not feel anger toward this country. The identification of this combination reinforces the importance of equifinality in animosity, to avoid the generalizations made in extant research.

\section{Managerial implications}

This study offers several important implications for international brand managers targeting potentially hostile markets with their products. In general, recognizing multiple forms of animosity suggests that marketers should always aim to identify and target consumers who match the form of animosity that can be more easily addressed. Causal combinations that explain NWOM or product avoidance but that show 1) the presence of quality perceptions and/or 2) the absence of one negative emotion, seem to indicate consumer subgroups who are less uniformly negative about the target country. It should 
therefore be easier to change their mind or at least assuage the hostile view of the target nation (Armitage and Conner, 2000).

This approach suggests that companies should not rely on general models of animosity but focus on exploring the drivers of animosity in their specific context, for their unique consumer segment. The identification of different animosity models should lead to the deployment of responses aligned with the motivations of a specific segment. For example, if animosity has not affected product quality perceptions, a company might benefit from deploying a communication campaign to improve perceptions of the target country. If, however, animosity has also affected product quality perceptions, the best solution might be to avoid any identification with the target nation (whenever this is feasible) and/or build stronger connections with host-country brands to compensate for the damage caused by animosity (see Fong, Lee and $\mathrm{Du}, 2014$ for an example of how this can be achieved).

Lastly, past animosity research indicates that marketers should always monitor the range of negative emotions expressed toward the target nation, since they predict the negative outcomes of animosity (Antonetti et al., 2019; Harmeling et al., 2015). We add to this recommendation the important caveat that marketers should consider which emotion matters most for the specific form of animosity that the company needs to overcome. For example, this research shows that fear, while extremely important in some configurations, plays no role in others. The study of consumer emotions needs to be therefore tailored to the specific form of animosity examined.

\section{Limitations and future research}

This analysis focuses on measuring consumer outcomes in the form of behavioral intentions. Despite its limitations, this is common practice in the animosity literature (Fong et al., 2014; Harmeling et al., 2015). Some studies, however, complement measures of 
intentions with information on actual product ownership (Gineikiene and Diamantopoulos, 2017). Further research can extend this typology to include measures of actual behavior. This might lead to the examination of whether consumers actually carry through with their intentions and therefore identify new types of animosity.

The analysis presented demonstrates the importance of heterogeneity in animosity responses but does not explicitly theorize the source of this different responses across subgroups. An important avenue for future research lies therefore in the development of a systematic theorizing of the factors that explain differences in responses to animosity. For example, future studies could theorize what explains the fact that fear and perceived quality play a different role across causal combinations as discussed above. While fsQCA allows identifying the diversity of causal recipes, it falls short of determining the reasons that explain such equifinality. This remains an important task to advance in future research.

Consistent with much of the literature (e.g., Harmeling et al., 2015), this study focuses on a cross-sectional examination of animosity and shows equifinality to be an important feature of this phenomenon. A pertinent question in this respect is whether over time the different models identified might converge or evolve in different directions. The adoption of a longitudinal approach in future research to track changes in individual perceptions (for example through repeated fsQCA studies) could answer this question.

This study suggests that, in a given international relation, different models of consumer animosity co-exist. At this stage, however, it is not clear what explains variations in causal recipes across crises. The current data shows a certain level of divergence between the China-Japan and the USA-China contexts. Given that animosity relates to the lasting effect of a crisis in international relations, our study focused on the negative impact of crisis in 
relations between the relevant countries and not one specific incident that took place during data collection. As noted previously, during the time of data collection, there were no specific incidents reported in the news that might have reignited the disputes and thus affected our results. As with all research, we need to recognize the limitation that our results are not generalizable beyond the contexts examined and the data collection period and thus results could be affected by different empirical contexts in terms of crises, countries and the effect of potential new incidents that might influence the international relation in a specific direction. Hence, it would be interesting to explore in more depth what causes such variations across crises (e.g., in our case variations between China-Japan and the USAChina contexts) and whether systematic factors affect these variations across other empirical contexts. In other words, theorizing should focus on the different features of crises that might affect consumer animosity (Brubaker and Laitin, 1998). To the best of our knowledge, no research exists on this point, as crises are merely considered as research contexts.

Lastly, following an approach common in animosity research (Harmeling et al., 2015), this study examines reactions to general products from the target country. Scholars should complement this approach by attempting to replicate these findings in specific industries. This would reveal whether the models of animosity identified are consistent across contexts or whether they depend on specific settings. 


\section{References}

Abosag, I. and Farah, M.F. (2014), “The influence of religiously motivated consumer boycotts on brand image, loyalty and product judgment", European Journal of Marketing, Vol. 48 No. 11/12, pp. 2262-2283.

Amine, L.S. (2008). “Country-of-origin, animosity and consumer response: marketing implications of anti-americanism and francophobia," International Business Review, Vol. 17 No. 4, pp. 402-22.

Antonetti, P. (2016), “Consumer anger: a label in search of meaning”, European Journal of Marketing, Vol. 50 No. 9/10, pp.1602-1628.

Antonetti, P., Manika, D. and Katsikeas, C. (2019), "Why consumer animosity reduces product quality perceptions: the role of extreme emotions in international crises", International Business Review, Vol. 28 No. 4, pp.739-753.

Armitage, C.J. and Conner, M. (2000), “Attitudinal ambivalence: a test of three key hypotheses", Personality and Social Psychology Bulletin, Vol. 26 No. 11, pp.14211432.

Asseraf, Y. and Shoham, A., (2016), “The 'tug of war' model of foreign product purchases", European Journal of Marketing, Vol. 50 No. 3/4, pp. 550-574.

Bagozzi, R.P. (2011), "Measurement and meaning in information systems and organizational research: methodological and philosophical foundations", MIS Quarterly, Vol. 35 No. 2, pp. 261-292.

Bagozzi, R.P. and Yi, Y. (1988), "On the evaluation of structural equation models", Journal of the Academy of Marketing Science, Vol. 16 No. 1, pp. 74-94. 
Brubaker, R. and Laitin, D.D. (1998), "Ethnic and nationalist violence", Annual Review of Sociology, Vol. 24 No. 1, pp. 423-452.

Byrne, B.M., Shavelson, R.J. and Muthén, B. (1989), “Testing for the equivalence of factor covariance and mean structures: the issue of partial measurement invariance", Psychological Bulletin, Vol. 105 No. 3, pp. 456-466.

Christensen, T.J. (1999), "China, the US-Japan alliance, and the security dilemma in East Asia”, International Security, Vol. 23 No. 4, pp. 49-80.

De Nisco, A., Mainolfi, G., Marino, V. and Napolitano, M.R. (2016), “Effect of economic animosity on consumer ethnocentrism and product-country images. A binational study on the perception of Germany during the Euro crisis", European Management Journal, Vol. 34 No. 1, pp. 59-68.

Ettenson, R. and Klein, J.G. (2005), “The fallout from French nuclear testing in the South Pacific: a longitudinal study of consumer boycotts", International Marketing Review, Vol. 22 No. 2, pp. 199-224.

Fiss, P.C. (2011), "Building better causal theories: a fuzzy set approach to typologies in organization research", Academy of Management Journal, Vol. 54 No. 2, pp. 393-420.

Fong, C.M., Lee, C.L. and Du, Y. (2014), “Consumer animosity, country of origin, and foreign entry-mode choice: a cross-country investigation", Journal of International Marketing, Vol. 22 No. 1, pp. 62-76.

Fong, J. and Burton, S. (2008), “A cross-cultural comparison of electronic word-of-mouth and country-of-origin effects", Journal of Business Research, Vol. 61 No. 3, pp. 233242. 
Fornell, C. and Larcker, D.F. (1981), "Evaluating structural equation models with unobservable variables and measurement error", Journal of Marketing Research, Vol. 18 No. 1 , pp. $39-50$

Funk, C.A., Arthurs, J.D., Treviño, L.J. and Joireman, J. (2010), “Consumer animosity in the global value chain: the effect of international production shifts on willingness to purchase hybrid products", Journal of International Business Studies, Vol. 41 No. 4, pp. 639-651.

Gineikiene, J. and Diamantopoulos, A. (2017), "I hate where it comes from but I still buy it: countervailing influences of animosity and nostalgia", Journal of International Business Studies, Vol. 48 No. 8, pp. 992-1008.

Greckhamer, T. (2016). CEO compensation in relation to worker compensation across countries: The configurational impact of country-level institutions. Strategic Management Journal, 37(4), 793-815.

Greckhamer, T., Misangyi, V.F. and Fiss, P.C. (2013), “The two QCAs: from a small-N to a large-N set theoretic approach" in Fiss, P.C., Cambre', B. and Marx, A. (Eds.), Configurational theory and methods in organizational research, Bingley: Emerald Group Publishing Limited, pp.49-75

Guido, G., Prete, M.I., Tedeschi, P. and Dadusc, L. (2010), "Effects of Jewish-Italian consumer animosity towards Arab products: the role of personality", Marketing Management Journal, Vol. 20 No. 1, pp. 1-18.

Harmeling, C.M., Magnusson, P. and Singh, N. (2015), "Beyond anger: a deeper look at consumer animosity”, Journal of International Business Studies, Vol. 108 No. 4, pp. 676-693. 
Heinberg, M. (2017), “Outbreaks of animosity against the West in China: effects on local brand consumption”, International Marketing Review, Vol. 34 No. 4, pp. 514-535.

Huang, Y.A., Phau, I. and Lin, C., (2010), “Consumer animosity, economic hardship, and normative influence", European Journal of Marketing, Vol. 44 No. 7/8, pp. 909-937.

Jedidi, K., Jagpal, H.S. and Desarbo, W.S. (1997), "Finite-mixture structural equation models for response-based segmentation and unobserved heterogeneity", Marketing Science, Vol. 16 No. 1, pp. 39-59.

Jung, K., Ang, S.H., Leong, S.M., Tan, S.J., Pornpitakpan, C. and Kau, A.K. (2002), “A typology of animosity and its cross-national validation", Journal of Cross-Cultural Psychology, Vol. 33 No. 6, pp. 525-539.

Klein, J. G. (2002), "Us versus them, or us versus everyone? Delineating consumer aversion to foreign goods", Journal of International Business Studies, Vol. 33 No. 2, pp. $345-363$.

Klein, J.G., Ettenson, R. and Morris, M.D. (1998), “The animosity model of foreign product purchase: an empirical test in the People's Republic of China", Journal of Marketing, Vol. 62 No. 1, pp. 89-100.

Lee, R. and Mazodier, M. (2015), “The roles of consumer ethnocentrism, animosity, and cosmopolitanism in sponsorship effects", European Journal of Marketing, Vol. 49 No. 5/6, pp. 919-942.

Lee, R., Lee, K.T. and Li, J. (2017), “A memory theory perspective of consumer ethnocentrism and animosity", European Journal of Marketing, Vol. 51 No. 7/8, pp. 1266-1285. 
Leigh, J. H. and Choi, Y. (2007), "The impact of attributions about life events on perceptions of foreign products: contrasts in individualism and collectivism", Psychology and Marketing, Vol. 24 No. 1, pp. 41-68.

Leischnig, A. and Woodside, A.G. (2017), "Who approves fraudulence? Configurational causes of consumers' unethical judgments", Journal of Business Ethics, Vol. 158 No. 3, pp. 713-726.

Leong, S.M., Cote, J.A., Ang, S.H., Tan, S.J., Jung, K., Kau, A.K. and Pornpitakpan, C. (2008), "Understanding consumer animosity in an international crisis: nature, antecedents, and consequences", Journal of International Business Studies, Vol. 39 No. 6, pp. 996-1009.

Liu, K. (2018), "Chinese manufacturing in the shadow of the China-US trade war", Economic Affairs, No. 38 Vol. 3, pp. 307-324.

Maher, A.A., Clark, P. and Maher, A. (2010), "International consumer admiration and the persistence of animosity", Journal of Consumer Marketing, Vol. 27 No. 5, pp. 414-424.

Meade, A.W. and Craig, S.B. (2012), "Identifying careless responses in survey data", Psychological Methods, Vol. 17 No. 3, pp.437-455.

Nunnally, J.C. (1978), Psychometric theory (2 ${ }^{\text {nd }}$ ed.), New York: McGraw-Hill.

O’Brien, R.M. (2007), “A caution regarding rules of thumb for variance inflation factors", Quality \& Quantity, Vol. 41 No. 5, pp. 673-690.

Oppenheimer, D.M., Meyvis, T. and Davidenko, N. (2009), "Instructional manipulation checks: Detecting satisficing to increase statistical power", Journal of Experimental Social Psychology, Vol. 45 No. 4, pp. 867-872. 
Podsakoff, P.M., MacKenzie, S.B., Lee, J.-Y. and Podsakoff, N.P. (2003), “Common method biases in behavioral research: a critical review of the literature and recommended remedies", Journal of Applied Psychology, Vol. 88 No. 5, pp. 879-903.

Ragin, C. C. (2000), Fuzzy-set social science, Chicago, IL: University of Chicago Press.

Ragin, C.C. (2006), "Set relations in social research: Evaluating their consistency and coverage", Political Analysis, Vol. 14 No. 3, pp. 291-310.

Ragin, C.C. (2008), Redesigning social inquiry: Fuzzy sets and beyond, Chicago, IL: University of Chicago Press.

Ragin, C.C. and Davey, S. (2016), Fuzzy-set/qualitative comparative analysis 3.0, Irvine, CA: Department of Sociology, University of California.

Ragin, C.C. and Fiss, P.C. (2008), "Net effects analysis versus configurational analysis: An empirical demonstration”, in Ragin, C.C. (Ed.), Redesigning social inquiry: Fuzzy sets and beyond, Chicago, IL: University of Chicago Press, pp.190-212.

Feng, E. (2020), "Hostility toward China is growing in the U.S., poll numbers show", NPR (2 Sept 2020), Accessed via: https://www.npr.org/2020/09/02/908874051/hostilitytoward-china-is-growing-in-the-u-s-poll-numbers-show.

Schlittgen, R., Ringle, C.M., Sarstedt, M. and Becker, J.M. (2016), "Segmentation of PLS path models by iterative reweighted regressions", Journal of Business Research, No. 69 Vol. 10, pp. 4583-4592.

Schneider, C.Q. and Wagemann, C. (2010), "Standards of good practice in qualitative comparative analysis (QCA) and fuzzysets", Comparative Sociology, Vol. 9 No. 3, pp. 397-418. 
Schneider, M.R. and Eggert, A. (2014), "Embracing complex causality with the QCA method: an invitation", Journal of Business Market Management, Vol. 7 No. 1, pp. $312-318$.

Shimp, T. A., Dunn, T. H. and Klein, J. G. (2004), "Remnants of the US Civil War and modern consumer behaviour", Psychology and Marketing, Vol. 21 No. 2, pp. 75-91.

Shoham, A., Davidow, M., Klein, J. and Ruvio, A. (2006), “Animosity on the home front: the Intifada in Israel and its Impact on consumer behavior.” Journal of International Marketing, Vol. 14 No. 3, pp. 92-114.

Steenkamp, J-B.E.M. and Baumgartner, H. (1998), “Assessing measurement invariance in cross-national consumer research", Journal of Consumer Research, Vol. 25 No. 1, pp. 78-90.

Urry, J. (2005), “The complexity turn”, Theory, Culture and Society, Vol. 22 No. 5, pp. 114.

Widaman, K. F. (1985), "Hierarchically nested covariance structure models for multitraitmultimethod data", Applied Psychological Measurement, Vol. 9 No. 1, pp. 1-26.

Woodside, A.G. (2013), "Moving beyond multiple regression analysis to algorithms: calling for adoption of a paradigm shift from symmetric to asymmetric thinking in data analysis and crafting theory", Journal of Business Research, Vol. 66 No. 4, pp. 463472.

Zyphur, M.J. (2009), “When mindsets collide: switching analytical mindsets to advance organization science", Academy of Management Review, Vol. 34 No. 4, pp. 677-688. 
Table 1. Measurements

\begin{tabular}{|c|c|c|c|c|}
\hline \multirow[t]{2}{*}{ Constructs } & \multicolumn{2}{|c|}{$\begin{array}{c}\text { Loadings } \\
\text { without } \\
\text { controlling for } \\
\text { CMB } \\
\end{array}$} & \multicolumn{2}{|c|}{$\begin{array}{c}\text { Loadings } \\
\text { controlling for } \\
\text { CMB }\end{array}$} \\
\hline & $\begin{array}{l}\text { China/ } \\
\text { Japan }\end{array}$ & $\begin{array}{l}\text { USA/ } \\
\text { China }\end{array}$ & $\begin{array}{l}\text { China/ } \\
\text { Japan }\end{array}$ & $\begin{array}{l}\text { USA/ } \\
\text { China }\end{array}$ \\
\hline \multicolumn{5}{|c|}{\begin{tabular}{|l|l|l} 
Military Animosity Beliefs $(\mathrm{CA}=.79 / .85, \mathrm{CR}=.79 / .82, \mathrm{AVE}=.57 / .61)$ & & \\
\end{tabular}} \\
\hline $\begin{array}{l}\text { There are frequent military disputes between Japan/China and } \\
\text { China/the USA. }\end{array}$ & .62 & .69 & .61 & .63 \\
\hline Japan/China and China/the USA are enemies. & .84 & .85 & .83 & .78 \\
\hline Japan/China is a threat to China's/the USA's national security. & .78 & .80 & .73 & .86 \\
\hline \multicolumn{5}{|l|}{ Anger $(\mathrm{CA}=.97 / .95, \mathrm{CR}=.97 / .96, \mathrm{AVE}=.88 / .84)$} \\
\hline Angry & .93 & .96 & .92 & .92 \\
\hline 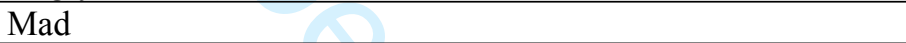 & .96 & .95 & .96 & .91 \\
\hline Frustrated & 93 & .88 & .92 & .92 \\
\hline Irritated & .94 & .88 & .94 & .92 \\
\hline \multicolumn{5}{|l|}{ Fear $(\mathrm{CA}=.88 / .95, \mathrm{CR}=.88 / .95, \mathrm{AVE}=.65 / .82)$} \\
\hline Scared & .92 & .94 & .87 & .91 \\
\hline Worried & .60 & .86 & .57 & .85 \\
\hline Fearful & .93 & .94 & .98 & .92 \\
\hline Anxious & .73 & .87 & .69 & .85 \\
\hline \multicolumn{5}{|l|}{ NWOM $(\mathrm{CA}=.96 / .93, \mathrm{CR}=.96 / .93, \mathrm{AVE}=.88 / .82)$} \\
\hline \multicolumn{5}{|l|}{$\begin{array}{l}\text { If a friend asked you for advice about a Japanese (Chinese) } \\
\text { product, how likely is it that you would say something negative } \\
\text { to discourage your friend? }\end{array}$} \\
\hline $\begin{array}{l}\text { Certain not to say something negative - Certain to say } \\
\text { something negative }\end{array}$ & .94 & .89 & .94 & .86 \\
\hline $\begin{array}{l}\text { Very unlikely to tell something negative - Very likely to tell } \\
\text { something negative }\end{array}$ & 93 & 91 & .92 & .89 \\
\hline $\begin{array}{l}\text { Probably would not say something negative: - Probably would } \\
\text { say something negative }\end{array}$ & .95 & 91 & 95 & .89 \\
\hline \multicolumn{5}{|l|}{ Product avoidance $(\mathrm{CA}=.96 / .94, \mathrm{CR}=.96 / .94, \mathrm{AVE}=.81 / .77)$} \\
\hline $\begin{array}{l}\text { If given the possibility, I would keep as much distance between } \\
\text { Japanese (Chinese) products and me. }\end{array}$ & .94 & .92 & 91 & 91 \\
\hline $\begin{array}{l}\text { If it was an option, I would avoid purchasing Japanese } \\
\text { (Chinese) products. }\end{array}$ & .92 & .91 & .87 & .89 \\
\hline I want nothing to do with Japanese (Chinese) products. & .87 & .85 & .85 & .83 \\
\hline $\begin{array}{l}\text { If possible, I would choose another product over a Japanese } \\
\text { (Chinese) product. }\end{array}$ & .87 & .84 & .91 & .85 \\
\hline $\begin{array}{l}\text { I would spend as little as possible on Japanese (Chinese) } \\
\text { products. }\end{array}$ & .91 & .86 & .91 & .85 \\
\hline \multicolumn{5}{|c|}{ Product Quality Perceptions $(\mathrm{CA}=.96 / .94, \mathrm{CR}=.96 / .94, \mathrm{AVE}=.85 / .80)$} \\
\hline $\begin{array}{l}\text { Japanese (Chinese) products are likely to be carefully } \\
\text { produced. }\end{array}$ & .95 & .92 & 94 & .86 \\
\hline $\begin{array}{l}\text { Japanese (Chinese) products are likely to have fine } \\
\text { workmanship. }\end{array}$ & .93 & .93 & 93 & \\
\hline $\begin{array}{l}\text { Japanese (Chinese) products are likely to have a high degree of } \\
\text { technological advancement. }\end{array}$ & .92 & .82 & .92 & .89 \\
\hline Japanese (Chinese) products are likely to be quite reliable & .89 & .91 & .88 & .88 \\
\hline
\end{tabular}

Note: All items measured on seven-point scales and borrowed from Harmeling, Magnusson and Singh, 2015. CA = Cronbach's alpha $\mathrm{CR}=$ composite reliability, $\mathrm{AVE}=$ average variance extracted. China/Japan (USA/China) is presented before (after) the $/$. 
Table 2. Descriptive statistics, correlations, and discriminant validity

\begin{tabular}{|l|c|c|c|c|c|c|c|c|}
\hline Constructs & $\mathbf{M}$ & SD & $\mathbf{1}$ & $\mathbf{2}$ & $\mathbf{3}$ & $\mathbf{4}$ & $\mathbf{5}$ & $\mathbf{6}$ \\
\hline 1. Military Animosity & $4.62 /$ & $1.19 /$ & $\mathbf{. 7 5 /}$ & & & & & \\
Beliefs & 3.84 & 1.30 & $\mathbf{. 7 8}$ & & & & & \\
\hline \multirow{2}{*}{ 2. Anger } & $4.32 /$ & $1.68 /$ & $.52^{* * /}$ & $\mathbf{. 9 4 /}$ & & & & \\
& 3.22 & 1.63 & $.54^{* *}$ &. $\mathbf{9 2}$ & & & & \\
\hline \multirow{2}{*}{ 3. Fear } & $2.89 /$ & $1.32 /$ & $.29^{* * /}$ & $.36^{* * /}$ & $\mathbf{. 8 1 /}$ & & & \\
\hline 4. Negative Word Of & 3.23 & $1.60 /$ & $.53^{* *}$ & $.64^{* *}$ & $\mathbf{. 9 0}$ & & & \\
Mouth & $3.67 /$ & $1.79 /$ & $.40^{* * /}$ & $.50^{* * /}$ & $.24^{* * /}$ & $\mathbf{. 9 4 /}$ & & \\
\hline \multirow{2}{*}{ 5. Product Avoidance } & 3.88 & 1.54 & $.41^{* *}$ & $.47^{* *}$ & $.39^{* *}$ & $\mathbf{. 9 0}$ & & \\
& $4.28 /$ & $1.64 /$ & $.49^{* * /}$ & $.60^{* * /}$ & $.22^{* * /}$ & $.69^{* * /}$ & $\mathbf{. 9 0 /}$ & \\
\hline 6. Product Quality & 4.25 & 1.53 & $.45^{* *}$ & $.51^{* *}$ & $.37^{* *}$ & $.67^{* *}$ & $\mathbf{. 8 8}$ & \\
Perceptions & $5.08 /$ & $1.27 /$ & $-.15^{* * /}$ & $-.27^{* * /}$ & $.04 /$ & $-.40^{* * /}$ & $-.44^{* * /}$ & $\mathbf{. 9 2 /}$ \\
\hline
\end{tabular}

$* * p<.01, * p<.05$.

Notes: $\mathrm{M}=$ mean; $\mathrm{SD}=$ standard deviation. The square root of the average variance extracted is reported on the diagonal in bold. China-Japan (USA-China) is presented before (after) the /. 
Table 3: FsQCA solutions explaining Chinese consumers' reactions toward Japan

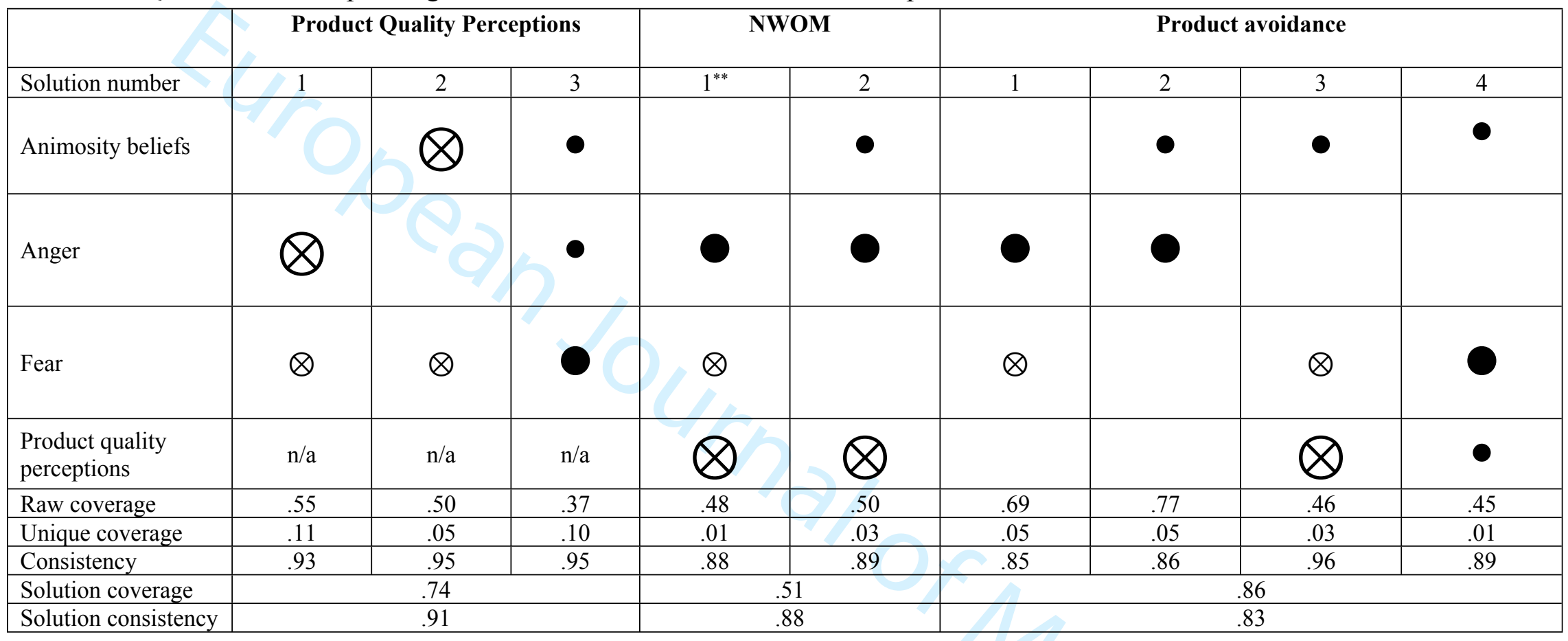

Notes: "•" indicates the presence and " $\otimes$ " indicates the negation of an antecedent condition; large circles indicate core conditions and small circles indicate peripheral conditions; analysis thresholds for product quality perceptions frequency $=28(94 \%$ of cases), consistency $=.95$; analysis thresholds for NWOM $=$ four $\left(99 \%\right.$ of cases), consistency $=.89$; analysis thresholds for product avoidance $=$ four $(99 \%$ of cases $)$, consistency $=.87$. ${ }^{* *}$ this casual recipe is dependent on the inclusion of a truth table row with PRI $=.48$. If this solution is excluded only one causal recipe is obtained. 
Table 4: FsQCA solutions explaining American consumers' reactions toward China

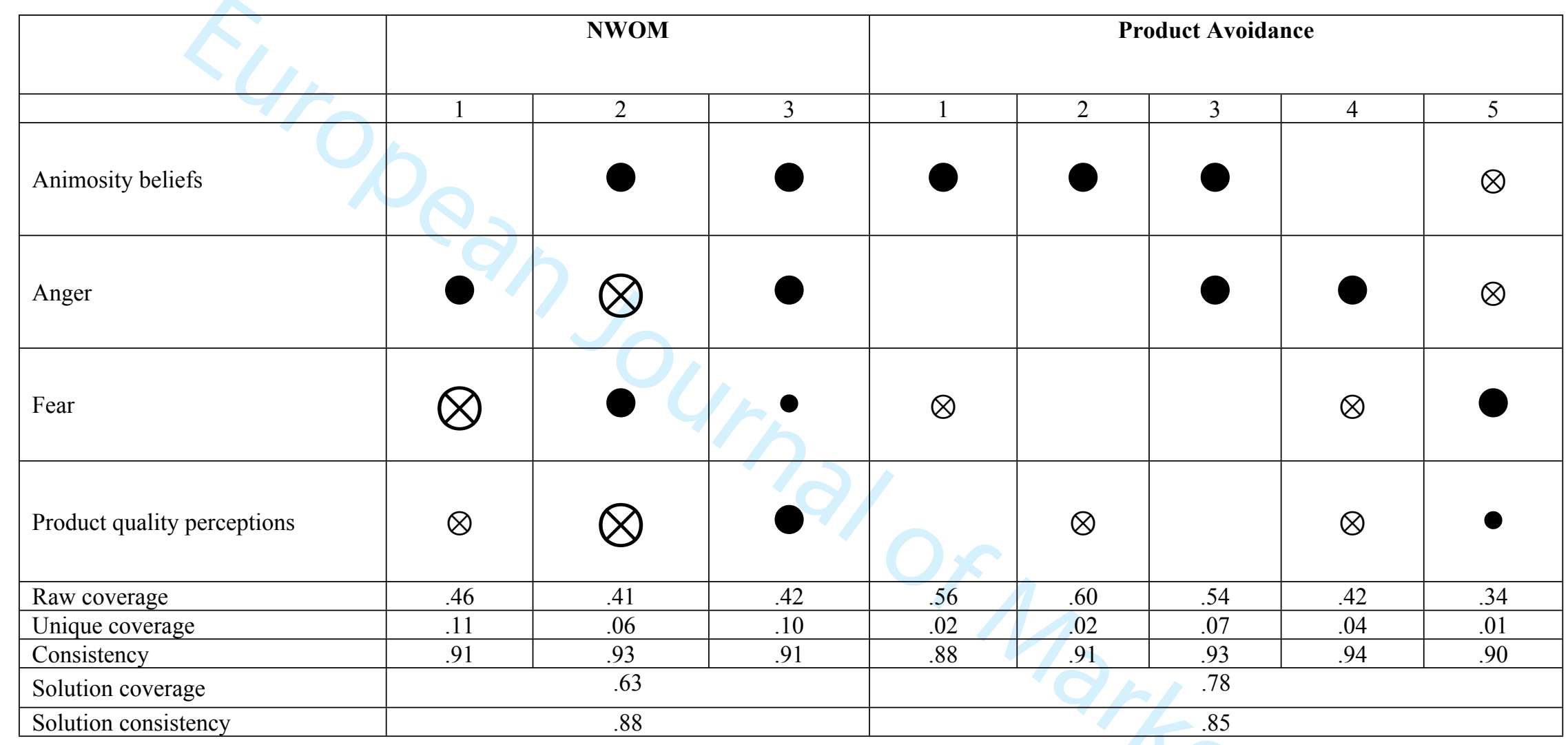

Notes: "•" indicates the presence and " $\otimes$ " indicates the negation of an antecedent condition; large circles indicate core conditions and small circles indicate peripheral conditions; analysis thresholds for NWOM $=10$ (93\% of cases), consistency $=.91$; analysis thresholds for product avoidance $=$ six $(99 \%$ of cases $)$, consistency $=.88$. 
Truth table 1: China-Japan, Product quality perceptions

\begin{tabular}{|c|c|c|c|c|c|c|c|c|c|}
\hline $\begin{array}{l}\text { Animosity } \\
\text { beliefs }\end{array}$ & Anger & Fear & Count & $\begin{array}{l}\text { Cumulative } \\
\text { proportion }\end{array}$ & $\begin{array}{c}\text { Consistency } \\
\text { PQ } \\
\text { Perceptions }\end{array}$ & $\begin{array}{c}\text { PRI } \\
\text { consistency PQ } \\
\text { Perceptions }\end{array}$ & $\begin{array}{c}\text { Consistency } \\
\sim P Q \\
\text { Perceptions }\end{array}$ & $\begin{array}{c}\text { PRI } \\
\text { consistency } \\
\sim \text { PQ } \\
\text { Perceptions } \\
\end{array}$ & $\begin{array}{l}\text { Row included } \\
\text { in the analysis }\end{array}$ \\
\hline 1 & 1 & 0 & 129 & $35.64 \%$ & 0.88 & 0.76 & 0.59 & 0.18 & No \\
\hline 1 & 0 & 0 & 73 & $55.80 \%$ & 0.97 & 0.92 & 0.58 & 0.06 & Yes \\
\hline 0 & 0 & 0 & 66 & $74.03 \%$ & 0.97 & 0.94 & 0.57 & 0.04 & Yes \\
\hline 1 & 1 & 1 & 59 & $90.33 \%$ & 0.95 & 0.89 & 0.60 & 0.09 & Yes \\
\hline 0 & 1 & 0 & 28 & $98.07 \%$ & 0.96 & 0.88 & 0.69 & 0.10 & Yes \\
\hline 1 & 0 & 1 & 4 & $99.17 \%$ & 0.99 & 0.97 & 0.72 & 0.03 & - \\
\hline 0 & 1 & 1 & 2 & $99.72 \%$ & 0.99 & 0.95 & 0.77 & 0.05 & - \\
\hline 0 & 0 & 1 & 1 & $100 \%$ & 0.99 & 0.98 & 0.78 & 0.02 & - \\
\hline
\end{tabular}


Truth table 2: China-Japan, Negative word of mouth

\begin{tabular}{|c|c|c|c|c|c|c|c|c|c|c|}
\hline $\begin{array}{c}\text { Animosity } \\
\text { beliefs }\end{array}$ & Anger & Fear & $\begin{array}{c}\text { Product } \\
\text { quality }\end{array}$ & Count & $\begin{array}{c}\text { Cumulative } \\
\text { proportion }\end{array}$ & $\begin{array}{c}\text { Consistency } \\
\text { NWOM }\end{array}$ & $\begin{array}{c}\text { PRI } \\
\text { NWOM }\end{array}$ & $\begin{array}{c}\text { Consistency } \\
\text { NWOM }\end{array}$ & $\begin{array}{c}\text { PRI } \\
\text { consistency } \\
\sim \text { NWOM }\end{array}$ & $\begin{array}{c}\text { Row included } \\
\text { in the analysis }\end{array}$ \\
\hline 1 & 1 & 0 & 1 & 89 & $26.81 \%$ & 0.76 & 0.45 & 0.79 & 0.52 & No \\
\hline 1 & 0 & 0 & 1 & 62 & $45.48 \%$ & 0.67 & 0.20 & 0.91 & 0.77 & No \\
\hline 0 & 0 & 0 & 1 & 57 & $62.65 \%$ & 0.62 & 0.12 & 0.94 & 0.86 & No \\
\hline 1 & 1 & 1 & 1 & 50 & $77.71 \%$ & 0.82 & 0.50 & 0.80 & 0.47 & No \\
\hline 1 & 1 & 0 & 0 & 30 & $86.75 \%$ & 0.89 & 0.67 & 0.78 & 0.33 & Yes \\
\hline 0 & 1 & 0 & 1 & 21 & $93.07 \%$ & 0.78 & 0.29 & 0.90 & 0.69 & No \\
\hline 1 & 0 & 0 & 0 & 5 & $94.58 \%$ & 0.88 & 0.42 & 0.91 & 0.56 & No \\
\hline 1 & 1 & 1 & 0 & 4 & $95.78 \%$ & 0.94 & 0.73 & 0.85 & 0.27 & Yes \\
\hline 1 & 0 & 1 & 1 & 4 & $96.99 \%$ & 0.83 & 0.29 & 0.93 & 0.70 & No \\
\hline 0 & 1 & 0 & 0 & 4 & $98.19 \%$ & 0.90 & 0.48 & 0.90 & 0.52 & Yes \\
\hline 0 & 0 & 0 & 0 & 3 & $99.10 \%$ & 0.86 & 0.31 & 0.94 & 0.68 & No \\
\hline 0 & 1 & 1 & 1 & 2 & $99.70 \%$ & 0.87 & 0.39 & 0.92 & 0.61 & No \\
\hline 0 & 0 & 1 & 1 & 1 & $100 \%$ & 0.86 & 0.26 & 0.95 & 0.73 & No \\
\hline 1 & 0 & 1 & 0 & 0 & & & & & & \\
\hline 0 & 1 & 1 & 0 & 0 & & & & & & \\
\hline 0 & 0 & 1 & 0 & 0 & & & & & \\
\hline
\end{tabular}


Truth table 3: China-Japan, Product avoidance

\begin{tabular}{|c|c|c|c|c|c|c|c|c|c|c|}
\hline $\begin{array}{c}\text { Animosity } \\
\text { beliefs }\end{array}$ & Anger & Fear & $\begin{array}{l}\text { Product } \\
\text { quality }\end{array}$ & Count & $\begin{array}{l}\text { Cumulative } \\
\text { proportion }\end{array}$ & $\begin{array}{l}\text { Consistency } \\
\text { Avoidance }\end{array}$ & $\begin{array}{c}\text { PRI } \\
\text { Avoidance }\end{array}$ & $\begin{array}{l}\text { Consistency } \\
\sim \text { Avoidance }\end{array}$ & $\begin{array}{c}\text { PRI } \\
\text { consistency } \\
\sim \text { Avoidance }\end{array}$ & $\begin{array}{l}\text { Row } \\
\text { included in } \\
\text { the analysis }\end{array}$ \\
\hline 1 & 1 & 0 & 1 & 89 & $26.81 \%$ & 0.87 & 0.71 & 0.68 & 0.27 & Yes \\
\hline 1 & 0 & 0 & 1 & 62 & $45.48 \%$ & 0.76 & 0.34 & 0.87 & 0.64 & No \\
\hline 0 & 0 & 0 & 1 & 57 & $62.65 \%$ & 0.70 & 0.20 & 0.92 & 0.77 & No \\
\hline 1 & 1 & 1 & 1 & 50 & $77.71 \%$ & 0.91 & 0.76 & 0.70 & 0.22 & Yes \\
\hline 1 & 1 & 0 & 0 & 30 & $86.75 \%$ & 0.98 & 0.93 & 0.69 & 0.06 & Yes \\
\hline 0 & 1 & 0 & 1 & 21 & $93.07 \%$ & 0.88 & 0.58 & 0.83 & 0.41 & Yes \\
\hline 1 & 0 & 0 & 0 & 5 & $94.58 \%$ & 0.96 & 0.75 & 0.87 & 0.25 & Yes \\
\hline 1 & 1 & 1 & 0 & 4 & $95.78 \%$ & 0.99 & 0.94 & 0.80 & 0.06 & Yes \\
\hline 1 & 0 & 1 & 1 & 4 & $96.99 \%$ & 0.90 & 0.54 & 0.88 & 0.45 & Yes \\
\hline 0 & 1 & 0 & 0 & 4 & $98.19 \%$ & 0.97 & 0.83 & 0.85 & 0.16 & Yes \\
\hline 0 & 0 & 0 & 0 & 3 & $99.10 \%$ & 0.94 & 0.59 & 0.92 & 0.40 & No \\
\hline 0 & 1 & 1 & 1 & 2 & $99.70 \%$ & 0.93 & 0.64 & 0.88 & 0.36 & No \\
\hline 0 & 0 & 1 & 1 & 1 & $100.00 \%$ & 0.91 & 0.43 & 0.93 & 0.57 & No \\
\hline 1 & 0 & 1 & 0 & 0 & & & & & & \\
\hline 0 & 1 & 1 & 0 & 0 & & & & & & \\
\hline 0 & 0 & 1 & 0 & 0 & & & & & & \\
\hline
\end{tabular}


Truth table 4: USA-China, Product quality perceptions

\begin{tabular}{|c|c|c|c|c|c|c|c|c|c|}
\hline $\begin{array}{c}\text { Animosity } \\
\text { beliefs }\end{array}$ & Anger & Fear & Count & $\begin{array}{c}\text { Cumulative } \\
\text { proportion }\end{array}$ & $\begin{array}{c}\text { Consistency } \\
\text { PQ } \\
\text { Perceptions }\end{array}$ & $\begin{array}{c}\text { PRI } \\
\text { consistency PQ } \\
\text { Perceptions }\end{array}$ & $\begin{array}{c}\text { Consistency } \\
\sim \text { PQ } \\
\text { Perceptions }\end{array}$ & $\begin{array}{c}\text { PRI } \\
\text { consistency } \\
\sim \text { PQ } \\
\text { Perceptions }\end{array}$ & $\begin{array}{c}\text { Row included } \\
\text { in the analysis }\end{array}$ \\
\hline 0 & 0 & 0 & 164 & $44.44 \%$ & 0.74 & 0.40 & 0.77 & 0.46 & - \\
\hline 1 & 1 & 1 & 72 & $63.96 \%$ & 0.82 & 0.52 & 0.79 & 0.45 & - \\
\hline 1 & 0 & 0 & 53 & $78.32 \%$ & 0.81 & 0.35 & 0.89 & 0.61 & - \\
\hline 1 & 1 & 0 & 21 & $84.01 \%$ & 0.83 & 0.27 & 0.93 & 0.71 & - \\
\hline 0 & 0 & 1 & 18 & $88.89 \%$ & 0.88 & 0.48 & 0.89 & 0.51 & - \\
\hline 0 & 1 & 0 & 17 & $93.50 \%$ & 0.82 & 0.21 & 0.95 & 0.77 & - \\
\hline 1 & 0 & 1 & 15 & $97.56 \%$ & 0.85 & 0.37 & 0.91 & 0.62 & - \\
\hline 0 & 1 & 1 & 9 & $100.00 \%$ & 0.88 & 0.35 & 0.93 & 0.63 & - \\
\hline
\end{tabular}


Truth table 5: USA-China, Negative word of mouth

\begin{tabular}{|c|c|c|c|c|c|c|c|c|c|c|}
\hline $\begin{array}{l}\text { Animosity } \\
\text { beliefs }\end{array}$ & Anger & Fear & $\begin{array}{l}\text { Product } \\
\text { quality }\end{array}$ & Count & $\begin{array}{l}\text { Cumulative } \\
\text { proportion }\end{array}$ & $\begin{array}{c}\text { Consistency } \\
\text { NWOM }\end{array}$ & $\begin{array}{c}\text { PRI } \\
\text { NWOM }\end{array}$ & $\begin{array}{c}\text { Consistency } \\
\sim \text { NWOM }\end{array}$ & $\begin{array}{c}\text { PRI } \\
\text { consistency } \\
\sim \text { NWOM } \\
\end{array}$ & $\begin{array}{l}\text { Row included } \\
\text { in the analysis }\end{array}$ \\
\hline 0 & 0 & 0 & 0 & 75 & 0.23 & 0.79 & 0.34 & 0.87 & 0.60 & No \\
\hline 0 & 0 & 0 & 1 & 64 & 0.43 & 0.70 & 0.10 & 0.95 & 0.86 & No \\
\hline 1 & 1 & 1 & 1 & 38 & 0.55 & 0.91 & 0.68 & 0.80 & 0.27 & Yes \\
\hline 1 & 0 & 0 & 0 & 30 & 0.65 & 0.86 & 0.45 & 0.88 & 0.51 & No \\
\hline 1 & 1 & 1 & 0 & 28 & 0.73 & 0.94 & 0.75 & 0.82 & 0.23 & Yes \\
\hline 1 & 0 & 0 & 1 & 16 & 0.78 & 0.83 & 0.28 & 0.93 & 0.70 & No \\
\hline 1 & 1 & 0 & 0 & 13 & 0.83 & 0.93 & 0.63 & 0.87 & 0.36 & Yes \\
\hline 0 & 0 & 1 & 1 & 13 & 0.87 & 0.88 & 0.28 & 0.95 & 0.70 & No \\
\hline 0 & 1 & 0 & 0 & 12 & 0.90 & 0.92 & 0.60 & 0.89 & 0.39 & Yes \\
\hline 1 & 0 & 1 & 0 & 10 & 0.93 & 0.93 & 0.64 & 0.87 & 0.36 & Yes \\
\hline 1 & 1 & 0 & 1 & 6 & 0.95 & 0.92 & 0.44 & 0.93 & 0.56 & No \\
\hline 1 & 0 & 1 & 1 & 4 & 0.97 & 0.92 & 0.47 & 0.93 & 0.53 & No \\
\hline 0 & 1 & 1 & 0 & 4 & 0.98 & 0.95 & 0.66 & 0.90 & 0.33 & No \\
\hline 0 & 0 & 1 & 0 & 3 & 0.99 & 0.93 & 0.56 & 0.91 & 0.44 & No \\
\hline 0 & 1 & 1 & 1 & 2 & 0.99 & 0.94 & 0.49 & 0.94 & 0.51 & No \\
\hline 0 & 1 & 0 & 1 & 2 & 1.00 & 0.92 & 0.37 & 0.95 & 0.63 & No \\
\hline
\end{tabular}


Truth table 6: USA-China, Product avoidance

\begin{tabular}{|c|c|c|c|c|c|c|c|c|c|c|}
\hline $\begin{array}{l}\text { Animosity } \\
\text { beliefs }\end{array}$ & Anger & Fear & $\begin{array}{l}\text { Product } \\
\text { quality }\end{array}$ & Count & $\begin{array}{l}\text { Cumulative } \\
\text { proportion }\end{array}$ & $\begin{array}{l}\text { Consistency } \\
\text { Avoidance }\end{array}$ & $\begin{array}{c}\text { PRI } \\
\text { Avoidance }\end{array}$ & $\begin{array}{l}\text { Consistency } \\
\sim \text { Avoidance }\end{array}$ & $\begin{array}{c}\text { PRI } \\
\text { consistency } \\
\sim \text { Avoidance } \\
\end{array}$ & $\begin{array}{l}\text { Row } \\
\text { included in } \\
\text { the analysis }\end{array}$ \\
\hline 0 & 0 & 0 & 0 & 75 & $23.44 \%$ & 0.83 & 0.52 & 0.80 & 0.44 & No \\
\hline 0 & 0 & 0 & 1 & 64 & $43.44 \%$ & 0.72 & 0.27 & 0.89 & 0.72 & No \\
\hline 1 & 1 & 1 & 1 & 38 & $55.31 \%$ & 0.96 & 0.85 & 0.73 & 0.14 & Yes \\
\hline 1 & 0 & 0 & 0 & 30 & $64.69 \%$ & 0.92 & 0.70 & 0.80 & 0.29 & Yes \\
\hline 1 & 1 & 1 & 0 & 28 & $73.44 \%$ & 0.96 & 0.86 & 0.76 & 0.13 & Yes \\
\hline 1 & 0 & 0 & 1 & 16 & $78.44 \%$ & 0.89 & 0.54 & 0.87 & 0.45 & No \\
\hline 1 & 1 & 0 & 0 & 13 & $82.50 \%$ & 0.96 & 0.84 & 0.79 & 0.15 & Yes \\
\hline 0 & 0 & 1 & 1 & 13 & $86.56 \%$ & 0.90 & 0.51 & 0.89 & 0.48 & Yes \\
\hline 0 & 1 & 0 & 0 & 12 & $90.31 \%$ & 0.94 & 0.77 & 0.82 & 0.23 & Yes \\
\hline 1 & 0 & 1 & 0 & 10 & $93.44 \%$ & 0.95 & 0.77 & 0.83 & 0.22 & Yes \\
\hline 1 & 1 & 0 & 1 & 6 & $95.31 \%$ & 0.95 & 0.71 & 0.87 & 0.29 & No \\
\hline 1 & 0 & 1 & 1 & 4 & $96.56 \%$ & 0.95 & 0.70 & 0.88 & 0.30 & No \\
\hline 0 & 1 & 1 & 0 & 4 & $97.81 \%$ & 0.97 & 0.81 & 0.85 & 0.19 & No \\
\hline 0 & 0 & 1 & 0 & 3 & $98.75 \%$ & 0.95 & 0.72 & 0.87 & 0.28 & No \\
\hline 0 & 1 & 1 & 1 & 2 & $99.38 \%$ & 0.96 & 0.73 & 0.88 & 0.27 & No \\
\hline 0 & 1 & 0 & 1 & 2 & $100.00 \%$ & 0.94 & 0.67 & 0.89 & 0.32 & No \\
\hline
\end{tabular}


Table 1. Measurements

\begin{tabular}{|c|c|c|c|c|}
\hline \multirow[t]{2}{*}{ Constructs } & \multicolumn{2}{|c|}{$\begin{array}{c}\text { Loadings } \\
\text { without } \\
\text { controlling for } \\
\text { CMB } \\
\end{array}$} & \multicolumn{2}{|c|}{$\begin{array}{c}\text { Loadings } \\
\text { controlling for } \\
\text { CMB }\end{array}$} \\
\hline & $\begin{array}{l}\text { China/ } \\
\text { Japan }\end{array}$ & $\begin{array}{l}\text { USA/ } \\
\text { China }\end{array}$ & $\begin{array}{l}\text { China/ } \\
\text { Japan }\end{array}$ & $\begin{array}{l}\text { USA/ } \\
\text { China }\end{array}$ \\
\hline \multicolumn{5}{|c|}{\begin{tabular}{|l|l|l} 
Military Animosity Beliefs $(\mathrm{CA}=.79 / .85, \mathrm{CR}=.79 / .82, \mathrm{AVE}=.57 / .61)$ & & \\
\end{tabular}} \\
\hline $\begin{array}{l}\text { There are frequent military disputes between Japan/China and } \\
\text { China/the USA. }\end{array}$ & .62 & .69 & .61 & .63 \\
\hline Japan/China and China/the USA are enemies. & .84 & .85 & .83 & .78 \\
\hline Japan/China is a threat to China's/the USA's national security. & .78 & .80 & .73 & .86 \\
\hline \multicolumn{5}{|l|}{ Anger $(\mathrm{CA}=.97 / .95, \mathrm{CR}=.97 / .96, \mathrm{AVE}=.88 / .84)$} \\
\hline Angry & .93 & .96 & .92 & .92 \\
\hline 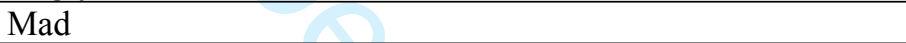 & .96 & .95 & .96 & .91 \\
\hline Frustrated & 93 & .88 & .92 & .92 \\
\hline Irritated & .94 & .88 & .94 & .92 \\
\hline \multicolumn{5}{|l|}{ Fear $(\mathrm{CA}=.88 / .95, \mathrm{CR}=.88 / .95, \mathrm{AVE}=.65 / .82)$} \\
\hline Scared & .92 & .94 & .87 & .91 \\
\hline Worried & .60 & .86 & .57 & .85 \\
\hline Fearful & .93 & .94 & .98 & .92 \\
\hline Anxious & .73 & .87 & .69 & .85 \\
\hline \multicolumn{5}{|l|}{ NWOM $(\mathrm{CA}=.96 / .93, \mathrm{CR}=.96 / .93, \mathrm{AVE}=.88 / .82)$} \\
\hline \multicolumn{5}{|l|}{$\begin{array}{l}\text { If a friend asked you for advice about a Japanese (Chinese) } \\
\text { product, how likely is it that you would say something negative } \\
\text { to discourage your friend? }\end{array}$} \\
\hline $\begin{array}{l}\text { Certain not to say something negative - Certain to say } \\
\text { something negative }\end{array}$ & .94 & .89 & .94 & .86 \\
\hline $\begin{array}{l}\text { Very unlikely to tell something negative - Very likely to tell } \\
\text { something negative }\end{array}$ & 93 & 91 & .92 & .89 \\
\hline $\begin{array}{l}\text { Probably would not say something negative: - Probably would } \\
\text { say something negative }\end{array}$ & .95 & 91 & 95 & .89 \\
\hline \multicolumn{5}{|l|}{ Product avoidance $(\mathrm{CA}=.96 / .94, \mathrm{CR}=.96 / .94, \mathrm{AVE}=.81 / .77)$} \\
\hline $\begin{array}{l}\text { If given the possibility, I would keep as much distance between } \\
\text { Japanese (Chinese) products and me. }\end{array}$ & .94 & .92 & 91 & 91 \\
\hline $\begin{array}{l}\text { If it was an option, I would avoid purchasing Japanese } \\
\text { (Chinese) products. }\end{array}$ & .92 & .91 & .87 & .89 \\
\hline I want nothing to do with Japanese (Chinese) products. & .87 & .85 & .85 & .83 \\
\hline $\begin{array}{l}\text { If possible, I would choose another product over a Japanese } \\
\text { (Chinese) product. }\end{array}$ & .87 & .84 & .91 & .85 \\
\hline $\begin{array}{l}\text { I would spend as little as possible on Japanese (Chinese) } \\
\text { products. }\end{array}$ & .91 & .86 & .91 & .85 \\
\hline \multicolumn{5}{|c|}{ Product Quality Perceptions $(\mathrm{CA}=.96 / .94, \mathrm{CR}=.96 / .94, \mathrm{AVE}=.85 / .80)$} \\
\hline $\begin{array}{l}\text { Japanese (Chinese) products are likely to be carefully } \\
\text { produced. }\end{array}$ & .95 & .92 & 94 & .86 \\
\hline $\begin{array}{l}\text { Japanese (Chinese) products are likely to have fine } \\
\text { workmanship. }\end{array}$ & .93 & .93 & 93 & \\
\hline $\begin{array}{l}\text { Japanese (Chinese) products are likely to have a high degree of } \\
\text { technological advancement. }\end{array}$ & .92 & .82 & .92 & .89 \\
\hline Japanese (Chinese) products are likely to be quite reliable & .89 & .91 & .88 & .88 \\
\hline
\end{tabular}

Note: All items measured on seven-point scales and borrowed from Harmeling, Magnusson and Singh, 2015. CA = Cronbach's alpha $\mathrm{CR}=$ composite reliability, $\mathrm{AVE}=$ average variance extracted. China/Japan (USA/China) is presented before (after) the /. 
Table 2. Descriptive statistics, correlations, and discriminant validity

\begin{tabular}{|l|c|c|c|c|c|c|c|c|}
\hline Constructs & $\mathbf{M}$ & SD & $\mathbf{1}$ & $\mathbf{2}$ & $\mathbf{3}$ & $\mathbf{4}$ & $\mathbf{5}$ & $\mathbf{6}$ \\
\hline 1. Military Animosity & $4.62 /$ & $1.19 /$ & $\mathbf{. 7 5 /}$ & & & & & \\
Beliefs & 3.84 & 1.30 & $\mathbf{. 7 8}$ & & & & & \\
\hline \multirow{2}{*}{ 2. Anger } & $4.32 /$ & $1.68 /$ & $.52^{* * /}$ & $\mathbf{. 9 4 /}$ & & & & \\
& 3.22 & 1.63 & $.54^{* *}$ &. $\mathbf{9 2}$ & & & & \\
\hline \multirow{2}{*}{ 3. Fear } & $2.89 /$ & $1.32 /$ & $.29^{* * /}$ & $.36^{* * /}$ & $\mathbf{. 8 1 /}$ & & & \\
\hline 4. Negative Word Of & 3.23 & $1.60 /$ & $.53^{* *}$ & $.64^{* *}$ & $\mathbf{. 9 0}$ & & & \\
Mouth & $3.67 /$ & $1.79 /$ & $.40^{* * /}$ & $.50^{* * /}$ & $.24^{* * /}$ & $\mathbf{. 9 4 /}$ & & \\
\hline \multirow{2}{*}{ 5. Product Avoidance } & 3.88 & 1.54 & $.41^{* *}$ & $.47^{* *}$ & $.39^{* *}$ & $\mathbf{. 9 0}$ & & \\
& $4.28 /$ & $1.64 /$ & $.49^{* * /}$ & $.60^{* * /}$ & $.22^{* * /}$ & $.69^{* * /}$ & $\mathbf{. 9 0 /}$ & \\
\hline 6. Product Quality & 4.25 & 1.53 & $.45^{* *}$ & $.51^{* *}$ & $.37^{* *}$ & $.67^{* *}$ & $\mathbf{. 8 8}$ & \\
Perceptions & $5.08 /$ & $1.27 /$ & $-.15^{* * /}$ & $-.27^{* * /}$ & $.04 /$ & $-.40^{* * /}$ & $-.44^{* * /}$ & $\mathbf{. 9 2 /}$ \\
\hline
\end{tabular}

$* * p<.01, * p<.05$.

Notes: $\mathrm{M}=$ mean; $\mathrm{SD}=$ standard deviation. The square root of the average variance extracted is reported on the diagonal in bold. China-Japan (USA-China) is presented before (after) the /. 
Table 3: FsQCA solutions explaining Chinese consumers' reactions toward Japan

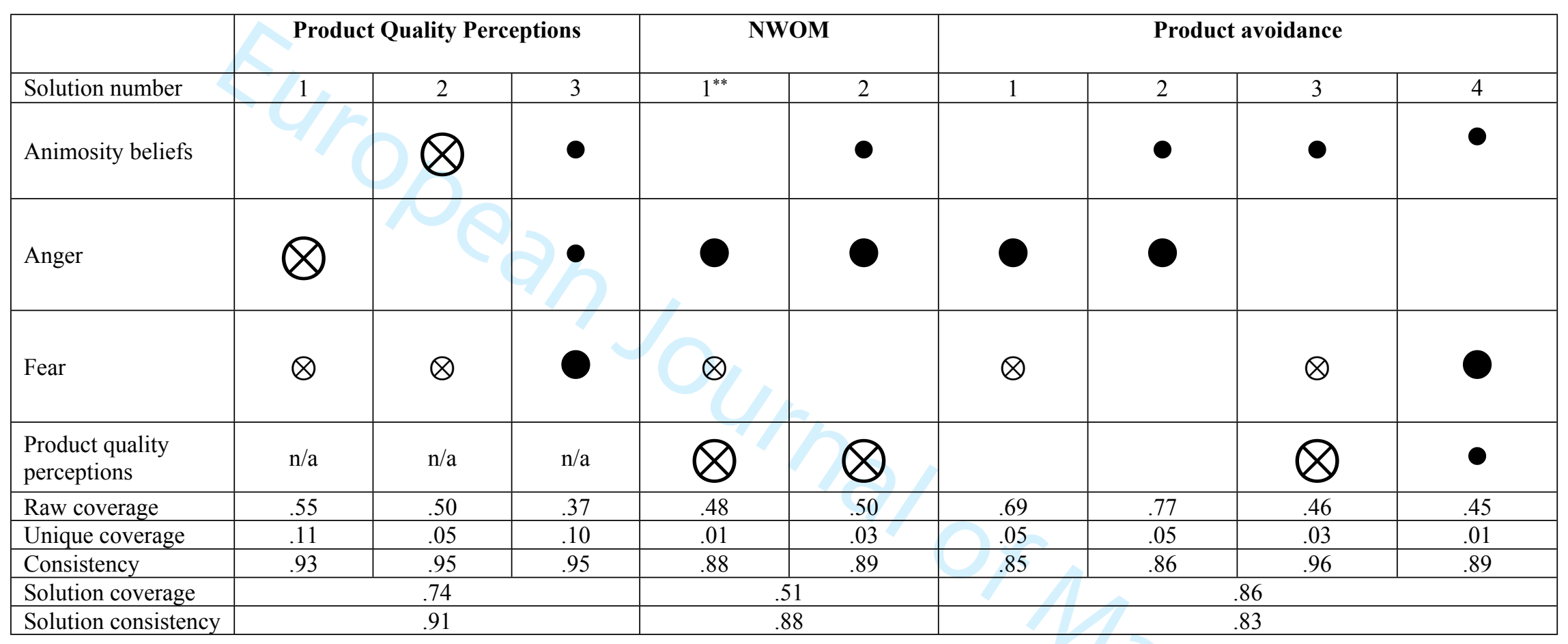

Notes: “ $\bullet$ indicates the presence and “ $\otimes$ " indicates the negation of an antecedent condition; large circles indicate core conditions and small circles indicate peripheral conditions; analysis thresholds for product quality perceptions frequency $=$ four ( $94 \%$ of cases), consistency $=.95$; analysis thresholds for NWOM $=$ four $(99 \%$ of cases $)$, consistency $=.89$; analysis thresholds for product avoidance $=$ four $\left(99 \%\right.$ of cases), consistency $=.87 .{ }^{* *}$ this casual recipe is dependent on the inclusion of a solution with PRI $=.48$. If this solution is excluded only one causal recipe is obtained. 
Table 4: FsQCA solutions explaining American consumers' reactions toward China

\begin{tabular}{|c|c|c|c|c|c|c|c|c|}
\hline 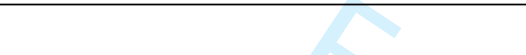 & \multicolumn{3}{|c|}{ NWOM } & \multicolumn{5}{|c|}{ Product Avoidance } \\
\hline 20 & 1 & 2 & 3 & 1 & 2 & 3 & 4 & 5 \\
\hline Animosity beliefs & & & & & D & & & $\otimes$ \\
\hline Anger & & & & & & & C & $\otimes$ \\
\hline Fear & $\bigotimes$ & & & $\otimes$ & & & $\otimes$ & \\
\hline Product quality perceptions & $\otimes$ & & & & $\otimes$ & & $\otimes$ & $\bullet$ \\
\hline Raw coverage & .46 & .41 & .42 & .56 & .60 & .54 & .42 & .34 \\
\hline Unique coverage & .11 & .06 & .10 & .02 & .02 & .07 & .04 & .01 \\
\hline Consistency & .91 & .93 & .91 & .88 & .91 & .93 & .94 & .90 \\
\hline Solution coverage & \multicolumn{3}{|c|}{.63} & \multicolumn{5}{|c|}{.78} \\
\hline Solution consistency & \multicolumn{3}{|c|}{.88} & \multicolumn{5}{|c|}{.85} \\
\hline
\end{tabular}

Notes: " $\bullet$ " indicates the presence and " $\otimes$ " indicates the negation of an antecedent condition; large circles indicate core conditions and small circles indicate peripheral conditions; analysis thresholds for $\mathrm{NWOM}=\operatorname{six}(93 \%$ of cases $)$, consistency $=.91$; analysis thresholds for product avoidance $=$ six $(99 \%$ of cases $)$, consistency $=.88$. 